Hispania Sacra, LXIII

128, julio-diciembre 2011, 433-467, ISSN: 0018-215-X

\title{
EL CURATO DE NATURALES EN SANTA FE. RÍO DE LA PLATA. SIGLOS XVII-XVIII
}

\author{
POR \\ Miriam MORICONI \\ U.N.R. - ISHIR-Cesor, CONICET
}

\section{RESUMEN}

La configuración de los poderes eclesiásticos coloniales es un tema que recorre una órbita mucho más extensa y compleja que la problemática de la conversión, el proceso de evangelización o la avanzada misional en los espacios fronterizos. La ciudad fue sede de poderes eclesiales cuyas actividades incluyeron tareas primordiales para la comunidad como eran la administración de justicia y el registro de los actos sacramentales de la feligresía. En la traza urbana de Santa Fe la configuración parroquial adoptó criterios de distinción socio étnica de los feligreses adscribiendo a sus residentes a uno u otro de los dos curatos según se tratase de españoles o naturales. Esta propuesta aborda la configuración del curato de naturales en Santa Fe del Río de la Plata indagando sus condiciones de existencia y funcionamiento.

PALABRAS CLAVE: parroquia, doctrinas, curato de naturales.

\section{THE NATIVE'S CURACY IN SANTA FE OF THE RÍO DE LA PLATA. XVII-XVIII CENTURIES}

\begin{abstract}
The configuration of the ecclesiastic colonial power is a topic that crosses a much more wide and complex orbit that the issue of the conversion, the process of evangelization or the advanced misional in border areas. The city was a headquarters of ecclesiastical authorities whose activities included basic tasks for the community as were the administration of justice and the record of the sacramental acts of the parish. In the urban setting of Santa Fe the parochial configuration adopted criteria for distinction socio-ethnic of the parishioners
\end{abstract}


assigning its residents to one or other one of both parishes as they were Spanish or natives. This proposal addresses the configuration of the native's curacy of Santa Fe del Rio de la Plata investigating its conditions of existence and functioning.

KEY WORDS: parish, doctrines, natives' parish, native's curacy.

Recibido/Received 20/01/2011

Aceptado/Accepted 15/04/2011

A finales del siglo XVIII, en el sureste de los dominios americanos de la Monarquía Hispánica, emplazada en la zona litoral paranaense de la región del Río de la Plata, la ciudad de Santa Fe de la Vera Cruz ${ }^{1}$ era un núcleo urbano pequeño que se proyectaba jurisdiccionalmente hacia un área inestable de población dispersa. ${ }^{2}$

\footnotetext{
${ }^{1}$ En las tramas institucionales que la administración monárquica católica disponía para el gobierno de sus territorios americanos interesa recordar que Santa Fe desde su fundación en 1573 estaba comprendida en el Virreinato del Perú. La ciudad y sus pagos, que a partir de 1617 eran parte de la Gobernación de Buenos Aires, en 1776 quedó integrada en una nueva delimitación, la del Virreinato del Río de la Plata. Asimismo, en relación a la configuración eclesiástica del territorio, Santa Fe estuvo integrada a la Arquidiócesis de Charcas. Desde su fundación fue parte del territorio diocesano del obispado del Río de la Plata, con sede en Asunción del Paraguay. A partir de 1620 y durante todo el período colonial formó parte de la diócesis de la Santísima Trinidad del Puerto de Buenos Aires. En 1859, con la creación de la diócesis de Paraná pasa a depender de esta jurisdicción y en 1865 el Papa Pío IX eleva a la diócesis del Río de la Plata con sede en Buenos a la categoría de Arquidiócesis. En el año1898 fue creada la diócesis de Santa Fe.

${ }^{2}$ Guaycurúes -con sus parcialidades abiponas, mocovíes y tobas- y parcialidades payaguas, chanás, mepenes, calchines, mocoretáes, quiloazas, charrúas, guaraníes, carcaráes, timbúes, calchaquíes, vilos, tocagües fueron, entre otras, las denominaciones utilizadas para designar a las etnías presentes en diferentes períodos en esta zona que de múltiples maneras se relacionaron entre sí y con los españoles. En el siglo XVIII, los calchaquíes y las parcialidades mocovíes y abiponas eran los más mentados pero, lógicamente no eran, no podían serlo, etnías «puras». Provenían de diferentes zonas y los procesos etnogenéticos dieron lugar a la formación de grupos que no tenían un pasado común y que se acoplaron y articularon como consecuencia de la conquista. Desde tiempos prehispánicos estos grupos indígenas tenían sus redes de intercambio, circulación de objetos y de individuos entre las distintas culturas. En el siglo XVI ante la presencia europea se acentúo la movilidad geográfica y finalmente, sobrevinieron las consecuencias de los traslados compulsivos de algunas comunidades, lo cual determina la imposibilidad de fijar estrictamente tanto su localización originaria como sus filiaciones étnicas. Se suma a la condición de estos factores de identificación el problema cognitivo que supone no disponer de registro escrito de estos pueblos y abordarlos a partir de nombres impuestos por los conquistadores. En el Litoral como en la zona pampeana si bien «la guerra constituyó un aspecto significativo de estas relaciones», tanto los malones conducidos por caciques indios como las campañas comandadas por las autoridades coloniales «se sucedieron alternando con períodos de relativa paz». Cfr. R. MANDRINI, «Las fronteras de la sociedad indígena en el ámbito pampeano» Anuario del IEHS 12 (1997) 23-34. Aunque aún no se dispone de bibliografía que brinde tendencias globales del mestizaje biológico, para ampliar el contexto etnohistórico y las condiciones de este espacio fronterizo en los siglos XVI y XVII puede consultarse: N. ARECES, C. DE BERnARDI, G. TARRAGÓ «Blancos e indios en el corredor fluvial
}

Hispania Sacra, LXIII

128, julio-diciembre 2011, 433-467, ISSN: 0018-215-X 
Los europeos e hispano criollos enunciaron la diversidad de esta población con categorías concebidas a partir de la matriz religiosa consustancial a la sociedad hispano católica; así, los pobladores integrados en el gobierno de la ciudad y sus pagos ${ }^{3}$ eran «almas» y aquellos que resistían serlo eran denominados «infieles». ${ }^{4}$ Estas categorías asumidas por el vocabulario imperial, también expresaron a escala local el fundamento ideológico del proyecto de expansión jurisdiccional de la Monarquía. 5

Desde temprano el discurso de la dominación colonial manifestó que el territorio fue pensado en términos religiosos y, durante el siglo XVIII, las comunidades que permanecían sueltas o aquellas otras que luego de transitar la experiencia reduccional retornaban a la «gentilidad», fueron el blanco de operaciones que -con diferentes tácticas, pero siempre con la impronta del imperativo de reducción bajo cruz y campana- se pergeñaron en el corredor litoral paranaense. Debido a la permanente inestabilidad de las fronteras, las autoridades ensayaron soluciones para el equipamiento del territorio santafesino ${ }^{6}$ en las

paranaense»; N. AReCES, S. LóPeZ, E. Regis y G. TARRAGó «La ciudad y los indios» y «Las tierras de la 'otra banda': Los charrúas y los vecinos santafesinos», todos en N. ARECES -compilador- Poder y sociedad: Santa Fe, la vieja 1573-1660, Rosario (1999). Para el siglo XVIII, entre otros citados en el desarrollo de este artículo, consultar: J. NoBILE Los pueblos originarios, Tomo I Nueva Historia de Santa Fe, Rosario, 2006; A. Damianovich, «Los inicios de la guerra ofensiva contra Mocovíes y Abipones. Las campañas santafesinas de 1728 y 1729» Revista de la Junta Provincial de Históricos de Santa Fe LVIII (1992) 153-172; A. LevagGI, Paz en la frontera. Historia de las relaciones diplomáticas con las comunidades indígenas en la Argentina (siglos XVI-XIX), Buenos Aires, 2000, en especial cap. 6, 52-62.

${ }^{3}$ Equivalentes al Alfoz de las villas ibéricas.

${ }^{4}$ No se conoce con exactitud la cantidad de habitantes de la villa santafesina en este período. El padrón de 1738 mandado a realizar por orden real, prospera en su realización en el pago de Los Arroyos pero «no se concreta, aparentemente, en la propia Santa Fe ni en Paraná, por la escasez de recursos existentes, y las reiteradas invasiones aborígenes» en H. VigLIONE, «Familias sin hombres» Temas Americanistas 20 (2008) 94:92-109.De acuerdo con Vicuña Mackena en 1755, Santa Fe contaba con 400 vecinos (2000 habitantes), en 1794 el cómputo de Félix de Azara es de 4500 habitantes; citados en M. CERvera, Historia de la ciudad y provincia de Santa Fe, T. II, 2da. edición, Santa Fe, 1980, pp. 5164. En 1795 el procurador Juan Teodoro de Larramendi comunicaba que «computadas las gentes de todas las calidades y estados asciende el numero de sus vecinos al de cuatro à cinco mil personas» en Informe del procurador Larramendi en 1795, M. CERVERA, Historia de la ciudad y provincia de Santa Fe, T. III, 2da. edición, Santa Fe, 1980, Apéndice, XXVII, p. 474.

5 «...comme un aspect tangible de la croissance de cet autre versant de l'Empire, non mesurable par le nombre des lieues, mais par celui des âmes» en D. BARRIERA, Vers une histoire politique configurationnelle. Conquérants, familles et rapports de pouvoir dans une ville aux confins de l'Empire espagnol (Santa Fe, Río de la Plata, XVI-XVII siècles), Lille, 2007, p.150.

${ }^{6}$ La noción de territorio como espacio políticamente equipado porta una larga historia conceptual. António Hespanha retomó las concepciones de los juristas medievales -territorium est spatium armatum iurisdictionis- en A.M. HeSPanha, La Gracia del Derecho, Madrid, 1993, pp. 102 y ss. Para el ámbito rioplatense Darío Barriera adapta el concepto de «ordenamiento territorial» propuesto por la geografía francesa. De acuerdo con su definición «equipamiento político de un territorio designa al proceso que incluye acciones de diversos agentes y de distinto tipo -que tienden a conseguir un resul- 
cuales confluyeron principalmente dos medidas: una militar -erección de línea de fortines -7 y otra religiosa, que perseguía la conversión del infiel y su permanencia en vida cristiana a través de la fundación y consolidación de reducciones, doctrinas y misiones. ${ }^{8}$

Este problema significó un punto nodal del gobierno colonial y, no sin razones, ha constituido una suerte de llave de entrada a las reflexiones en torno al rol desempeñado por el clero. Sin embargo, la configuración de los poderes eclesiásticos coloniales es un tema que recorre una órbita mucho más extensa y compleja que la problemática de la conversión, el proceso de evangelización o la avanzada misional en los espacios fronterizos. ${ }^{9}$ La presencia eclesiástica era parte instituyente de la vida urbana colonial.

Santa Fe, desde de su primer sitio, ${ }^{10}$ fue sede de poderes eclesiales cuyas actividades incluyeron tareas primordiales para el buen gobierno de la república

tado orientado por esta voluntad de ordenamiento- y las expresiones simbólicas o físicas que este accionar va imprimiendo tanto en el terreno como en la concepción de su relación con las instituciones políticas», en D. BARRIERA, « Un rostro local de la Monarquía Hispánica: justicia y equipamiento político del territorio al sureste de Charcas, siglos XVI-XVII» CLAHR, Vol. 15, 4 (2010) 378-379.

${ }^{7}$ F. CERVERA, «Reseña histórica del período de gobierno hispánico»; «Milicias santafesinas» en Historia de las Instituciones de la Provincia de Santa Fe, Tomo III, Santa Fe, 1970, pp. 18- 35; C. Battcock, C. Gotta y A. Manavella, «Frontera y poder: milicias y misiones en la jurisdicción de Santa Fe de la Vera Cruz, 1700-1780. Algunas reflexiones» Cuicuilco [en línea] 2004, 11 (enero-abril) [fecha de consulta: 5 de marzo de 2010] Disponible en: http://redalyc.uaemex; C. BATTCOCK, «La Frontera en tiempos de reformas. El Fuerte de Melincué: punto neurálgico en el sur santafesino» EHN 41, julio-diciembre (2009) 105-131.

${ }^{8}$ La crónica y la historiografía han coincidido al conceder al Teniente de Gobernador Francisco Javier Echagüe y Andía (1733-1742) el galardón de la excepcionalidad en lo que respecta a su gestión de los problemas indígenas que dificultaban la estabilización del territorio santafesino. De acuerdo con Furlong, «...durante su gobierno no sólo supo conquistar ya por la fuerza, ya por la persuasión a los [...] Mocovíes sino también a los terribles Abipones»-G. FurLong, Entre los Abipones del Chaco, Buenos Aires, 1938, p. 75-. Lo que extrañaba a los cronistas era que mientras en otras ciudades estos indios tenían «en consternación y terror a los españoles», en Santa Fe se hallaban en amigables relaciones. Esta apreciación no parece haberse construido con base en datos apócrifos o percepciones tergiversadas de la realidad. En las sesiones capitulares el Tte. Gobernador, había comunicado que con motivo de la «paz» que, desde hacía siete años, la ciudad mantenía con las «naciones de indios infieles abipones y mocovíes», los caciques habían solicitado reducción con su tribu. AGSF, Actas de Cabildo, Tomo XI, f 53 a f 54v. Santa Fe, 27 de Junio de 1741.

${ }^{9}$ Por otra parte, como ha señalado Barral analizando las últimas producciones sobre las misiones guaraníes, la misión no era un espacio homogéneo, impermeable y aislado. M. E. BARRAL, «'Guaraníes misioneros' reexaminados. Acerca del discutido papel de los curas y la religión en la conflictividad política latinoamericana (fines del siglo XVIII y principios del XIX)» Nuevo Mundo Mundos Nuevos, Debates (2009) [En línea] Disponible en http://nuevomundo.revues.org/index58055.html. Consultado el 10 marzo de 2010.

${ }^{10} \mathrm{La}$ ciudad de Santa Fe en la década de 1650-1660 fue mudada a un nuevo sitio y a esto refiere el uso de los topónimos Santa Fe la vieja (actualmente Cayastá) y Santa Fe de la Vera Cruz (hoy la ciudad de Santa Fe). En el traslado se respetó la traza original, hecho constatado documentalmente por el mandato de su fundador Juan de Garay y, arqueológicamente, por el trabajo pionero de Agustín Zapata Go-

Hispania Sacra, LXIII

128, julio-diciembre 2011, 433-467, ISSN: 0018-215-X 
entre las que destacan la administración de justicia y el registro de los actos más importantes de los miembros de esta comunidad. Desde el ingreso a la vida cristiana en el acto sacramental del bautismo, pasando por el matrimonio hasta la última estela material y simbólica que, en esta tierra, tras la muerte, dejaban el funeral y el ritual del enterramiento, eran asentados en los libros parroquiales. Estos registros y las directrices sobre cómo debían realizarse constituyen pruebas de las concepciones socioétnicas y de las preocupaciones relativas al problema que significaba ajustar los aspectos más cotidianos a los esquemas administrativos coloniales.

Teóricamente, españoles e indios debían habitar lugares separados. Los primeros tenían prohibido instalarse en pueblos de indios y éstos últimos tampoco podían residir en la traza urbana. Pero la vida en la ciudad requirió de su presencia y, como, en otras áreas de la América hispánica, las leyes que prescribían la segregación espacial en dos 'naciones', no siempre fueron aplicadas. ${ }^{11}$

En Santa Fe de la Vera Cruz, como en otras ciudades americanas, se admitieron negros para realizar el trabajo esclavo e indios para el servicio personal o yanaconazgo necesarios para su práctico funcionamiento. Si la pretensión de la separación física entre estos grupos quedó aniquilada en esta convivencia y proximidad urbana, no sucedió lo mismo en cuanto a la configuración parroquial ya que conservándose intacto este criterio, la participación religiosa estuvo vinculada a la gradación socioétnica. ${ }^{12}$

llán en el año 1949. «Fue, por consiguiente, la actual ciudad un calco o réplica de la antigua, tan exacto que conservó hasta la misma distribución de los sepulcros», en A. ZAPATA GoLLÁN, «Las ruinas de la primitiva ciudad de Santa Fe. Las tres Iglesias» en Obra completa, T.4, Santa Fe, 1990, p. 31.

11 N. SÁNCheZ-AlbornOZ, «La población de la América colonial española» en L. Bethell (ed.), Historia de América Latina, Barcelona, Vol. IV, 1990, p. 29. Para la capital novohispana se ha observado que «A medida que nos adentramos en el siglo XVIII y a la par de los cambios demográficos, económicos y sociales que vivía la ciudad de México, esta contradicción se acentuaba cada vez más dado que se acrecentaba el asentamiento de población indígena en la traza, y de españoles y castas en las parcialidades de indios» en E. SÁNCHEZ SANTIRÓ, «El nuevo orden parroquial de la ciudad de México: población, etnia y territorio (1768-1777)» EHN 30 (2004), p. 74.

12 Esto mismo ha sido analizado en otras configuraciones eclesiásticas. Para el caso de Buenos Aires Emir Reitano identificó que «En las iglesias en general había dos misas, la del alba y la de la una. La primera era frecuentada por las gentes de menores medios, los sirvientes, los esclavos y otros; la segunda por la 'gente decente'». Lo mismo observó respecto de los portugueses que habitaron el Río de la Plata quienes, aún siendo considerados «extranjeros» y discriminados en el trato de parte de las autoridades eclesiásticas, reproducían iguales criterios -prestigio social, liderazgo, gradación socioétnica- en sus propias comunidades y en sus cofradías: «El comportamiento de dicha comunidad era diferente de acuerdo a los estratos en que se integraban sus miembros, ya que, durante el período colonial existía una participación religiosa vinculada a la estratificación social», en E. REITANO «Iglesia y extranjeros en el Buenos Aires tardocolonial. El caso de los portugueses y su religiosidad» Anuario del Instituto de Historia Argentina 4 (2004) 161-166. 
El caso que presenta este espacio es el de una feligresía distinguida de acuerdo a su pertenencia a dos curatos - uno de españoles y otro de naturalesque si bien no tuvieron una expresión territorial apartada, conservaron servicios sacramentales y litúrgicos que se administraron y registraron diferenciadamente hasta el año 1787.

El estudio de esta particular configuración eclesiástica vinculada a la cura de almas de una heterogénea feligresía de indios, negros, mulatos, pardos y mestizos conviviendo conflictivamente con la parroquia de españoles, esboza la diversidad institucional y la complejidad de las dinámicas relacionales entre clérigos, entre párrocos y autoridades diocesanas, entre curas y feligreses, entre feligreses adscriptos a las distintas feligresías que hasta el momento no han sido sistemáticamente analizadas en la historiografía santafesina.

Esta última no alcanzó a beneficiarse de las producciones suscitadas por el interés en las dimensiones socio políticas de las agencias eclesiásticas y de la vida religiosa colonial americana, como puede constarse en las historiografías sobre el área mexicana y, más recientemente, la peruana.

Aún cuando en las últimas décadas esta tendencia ya se han manifestado en Argentina acusando una progresión de trabajos que se presentan como un promisorio avance en la historiografía sobre el Río de la Plata, ${ }^{13}$ es evidente la disparidad entre las producciones que se han ocupado de las áreas bonaerense, centro y noroeste ${ }^{14}$ del virreinato respecto de las que se disponen para una importante franja del obispado de Buenos Aires como era la del Litoral paranaense en la que, en el período analizado, estaba comprendido el territorio santafesino.

13 Un balance historiográfico que en gran medida refleja las condiciones de este campo en el presente en G. CARETTA y I. ZACCA, «Preguntas en el camino», en G. CARETTA y I. ZACCA (compiladoras) Para una historia de la Iglesia. Itinerarios y estudios de caso, Salta, 2008, pp. 11-17. Asimismo el ensayo bibliográfico final de R. Di Stefano y L. ZanatTa, Historia de la Iglesia Argentina, Buenos Aires, 2000.

${ }^{14}$ M. E. BARRAL, «Iglesia, poder y parentesco en el mundo rural colonial. La cofradía de Ánimas benditas del Purgatorio, Pilar, 1774», Cuadernos de Trabajo 10 (1998) 15-56; Sociedad, Iglesia y Religión en el mundo rural bonaerense, 1770-1810. Tesis doctoral. Universidad Pablo de Olavide, Sevilla, 2001; De sotanas por la Pampa. Religión y sociedad en el Buenos Aires rural tardocolonial, Buenos Aires, 2007. V. Ayrolo, «Representaciones sociales de los eclesiásticos cordobeses de principios del siglo XIX» Andes 11 (2000) pp. 161-175; «Cura de almas. Aproximación al clero secular de la diócesis de Córdoba del Tucumán en la primera mitad del siglo XIX» Anuario del IEHS 16 (2001) 421-443; «De sacerdotes a 'curas de almas'. Perfiles eclesiásticos del obispado de Córdoba entre la colonia y el final de la autonomía provincial» Actas X Jornadas Interescuelas/Departamentos de Historia, Rosario (2005); «Crónicas de un cura doctrinero de principios del siglo XIX. Sociedad, población y economía en el Valle de Famatina, La Rioja, del virreinato del Río de la Plata» Hispania Sacra 119 (2007) 303321; G. Vidal y P. Vagliente (compiladores) Por la señal de la Cruz. Estudios sobre Iglesia Católica y Sociedad en Córdoba, s. XVII -XX, Ferreira Editor, 2001. G. CARETTA, «Con el poder de las palabras y los hechos. El clero colonial de Salta entre 1770 y 1820», en S. Mata (compiladora) Persistencias y cambios: Salta y noroeste argentino.1770-1840, Rosario, 1999, pp. 81-117.

Hispania Sacra, LXIII

128, julio-diciembre 2011, 433-467, ISSN: 0018-215-X 
Aquí, los fondos del Archivo Histórico del Arzobispado de Santa Fe de la Vera Cruz, ${ }^{15}$ y otros disponibles en Santa Fe en el Archivo General de la Provincia ${ }^{16}$ y en el Departamento de Estudios Etnográficos y Coloniales, más la documentación adicional que se halla bajo la guarda del Archivo General de la Nación, constituyen una prueba del caudal de los repositorios que no condice con el deficitario estado historiográfico que para otros campos temáticos, o en otros lugares, pudo revertirse con el retorno a la democracia en los años 1980s. ${ }^{17}$

En algunas obras enfocadas al ámbito más global del Río de la Plata ${ }^{18}$ se han identificado las estructuras clericales y explicado las dinámicas eclesiásticas que contribuyen a la comprensión de las condiciones que compartía el territorio santafesino por hacer parte de ese espacio, pero todavía es muy acotado el conocimiento de esta experiencia. En el caso santafesino, si bien algunos avances puntuales han incidido tangencialmente en este campo temático, ${ }^{19}$ se sabe muy

\footnotetext{
${ }^{15}$ En adelante AHASFVC.

${ }^{16}$ En adelante AGSF.

${ }^{17}$ R. DI StEFANO, «De la teología a la historia: un siglo de lecturas retrospectivas del catolicismo argentino» Prohistoria 6 (2002) 173-20; D. BARRIERA, «La historia del poder político sobre el período temprano colonial rioplatense: razones de una ausencia, propuestas para una agenda» Penélope: Revista de Historia y Ciéncias Sociais 29 (2006) 133-159.

18 J. PeIRE El Taller de los Espejos. Iglesia e Imaginario, 1767-1815, Claridad, Buenos Aires, 2000; R. DI Stefano y L. Zanatta, Historia de la Iglesia Argentina, Buenos Aires, 2000; R. DI StefaNO, «Abundancia de clérigos, escasez de párrocos: las contradicciones del reclutamiento del clero secular en el Río de La Plata (1170-1840)» Revista del Instituto Ravignani Tercera serie 16-17 (1998); El púlpito y la plaza. Clero, sociedad y política de la Monarquía católica a la República rosista, Buenos Aires, 2004.

19 Debido a la incidencia tangencial de estas producciones no es posible un listado exhaustivo. Sólo diremos que del conjunto de ellas se distinguen dos tentativas: una, la de los análisis sobre las reducciones o pueblos de indios en tanto encuadramientos poblacionales paradigmáticos de la explotación económica en propiedades eclesiásticas - L. M. Calvo, La Compañía de Jesús en Santa Fe. La ocupación del espacio urbano y rural durante el dominio hispánico, Santa Fe, 1993; D. G. BARRIERA, M. del R. Baravalle y N. PeÑalba, «Estrategas competentes: La incorporación de las estancias del Cululú al patrimonio del Colegio de la Compañía de Jesús, 1610-1640» en AreCes, Nidia (comp.) Poder y sociedad: Santa Fe, la vieja 1573-1660, Rosario, 1999; N. ARECES, «Jesuitas y viajeros en el espacio colonial: La Compañía de Jesús en Santa Fe, 1610-1767. Las tramas del poder» en Estudios históricos regionales en el espacio rioplatense: de la Colonia a mediados del siglo XIX, Santa Fe, 2004, pp. 13-43; D. G. Barriera, M. del R. Baravalle y N. PeÑalba, «Misioneros de frontera: Los jesuitas durante el siglo XVII» en BARrIERA, Darío G. Economía y Sociedad (Siglos XVI a XVIII), Tomo III de Nueva historia de Santa Fe, Rosario, 2006- Otra, la de aquellos que analizando el rol de la administración de justicia, la agencia de las autoridades civiles en el proceso de fijación de pobladores y los modos de incorporación al territorio de las áreas más alejadas del núcleo urbano vislumbraron la impronta de las agencias eclesiásticas en el territorio -T. SUAREZ y L. TORNAY, «Familias vagantes y gentes de mal vivir en Santa Fe. Decisiones políticas sobre la frontera en el último cuarto del siglo XVIII», en Actas II Encuentro de Historia Regional Comparada, U.N.R., 12 y 13 de mayo de 2000; L. TORNAY, «La justicia rural en Santa Fe colonial. Cambios institucionales y sociales en el período borbónico», en IV Encuentro de Historiadores Santa Fe, 27 de septiembre de 2002, Santa Fe, 2003;
} 
poco acerca de las instituciones y de los agentes eclesiásticos de este período. El interés se orientó exclusivamente al estudio de la acción de los jesuitas y el rol que desempeñó la Compañía de Jesús en la experiencia reduccional santafesina hegemoniza el repertorio bibliográfico más nutrido. Pero ni la orden ignaciana representó el único sector eclesiástico que detentó propiedades, ${ }^{20} \mathrm{ni}$ gozaron del monopolio de la experiencia evangelizadora. Franciscanos -que los antecedieron y sucedieron después de la expulsión- dominicos y mercedarios estuvieron presentes en el territorio desplegando un amplio abanico de dispositivos, no todos ellos exclusivamente asociados a la coerción material, ni a las explotaciones rurales. ${ }^{21}$

Por otra parte, hubo pequeños núcleos en las áreas rurales ajenos a la experiencia reduccional o de fronteras donde las parroquias fueron prácticamente las únicas sedes del poder institucional eclesiástico. ${ }^{22} \mathrm{Y}$ en las ciudades, como sucedió en Santa Fe, la configuración parroquial representó un tablado de posibilidades relacionales entre los agentes eclesiásticos y entre estos y los reales o potenciales feligreses que ameritan su estudio.

Tomando esta posta sugerida en el conjunto de las observaciones sobre las áreas de vacancia de la historiografía santafesina y, retomando la propuesta de Barral en cuanto a indagar otras formas de influencia eclesiástica «más allá de la propiedad de la tierra y de la conformación de establecimientos agropecuarios», ${ }^{23}$ se escoge como punto de partida para este análisis la configuración del curato o parroquia de naturales.

T. SuAREZ y L. Tornay, «Poblaciones, vecinos y fronteras rioplatenses. Santa Fe a fines del siglo XVIII», en Anuario de Estudios Americanos, 60 (2003) 521- 555; D. BARRIERA, «La ciudad y las varas: justicia, justicias y jurisdicciones», en Revista de Historia del Derecho, 31 (2003); C. B ВТTTCOCK, C. GоTTA y A. Manavella (2004), Idem; C. B ATTCOCK, (2009) Idem.

${ }^{20}$ Aunque no hay para Santa Fe ningún estudio sistemático como el que ha realizado Barral para Buenos Aires, hay evidencias de ello en los distintos fondos documentales consultados para esta investigación. Ver M. E. Barral «Las propiedades rurales eclesiásticas en el Río de la Plata (Buenos Aires rural en el siglo XVIII y principios del XIX)», en B. Bodinier, R. Congost y P. LunA (editores) De la Iglesia al Estado. Las desamortizaciones de bienes eclesiásticos en Francia, España y América Latina, Zaragoza, 2010; pp. 105-127.

${ }^{21}$ M. E. BARRAL (2007), p. 80; «Disciplina y civilidad en el mundo rural de Buenos Aires a fines de la Colonia» Jahrbuch für Geschichte Lateinamerikas 44 (2007). Para Santa Fe: G. FurLong (SJ), Historia del Colegio de la Inmaculada de la ciudad de Santa Fe y de sus irradiaciones culturales, Buenos Aires, 1962.

22 Sería pertinente, en este sentido, analizar las experiencias de las parroquias del Pago de los Arroyos, el Pago de Bajada y Coronda como se ha hecho en la campaña bonaerense. Al respecto: M. E. BARRAL, «Las parroquias rurales de Buenos Aires entre 1730 y 1820» Andes 15 (2005) 19-54.

${ }^{23}$ M. E. BARRAL, «Los párrocos como mediadores en las fronteras del mundo colonial (Buenos Aires rural en el siglo XVIII)», en D. G. BARRIERA (compilador) Justicias y Fronteras. Estudios sobre la historia de la justicia en el Río de la Plata (Siglos XVII a XIX), Murcia, 2009, p. 68.

Hispania Sacra, LXIII

128, julio-diciembre 2011, 433-467, ISSN: 0018-215-X 


\section{Un TEMPlo PARA SAN RoQue, la PARRoQuia de nATURALES EN SANTA FE}

Antes del traslado de la ciudad, en Santa Fe la Vieja, había sido construida precariamente y puesto bajo la advocación de San Roque ${ }^{24}$ una iglesia destinada a las prácticas cultuales y la administración de los sacramentos a los naturales. Desconocemos las circunstancias y la fecha exacta en la que fue erigido el templo, 25 por el contrario, consta que el 12 de septiembre de 1616 el Cabildo estableció que, al finalizar «la obra del bienaventurado san roque», la inauguración se celebrase con misas, procesión y sermón a los cuales debían asistir vecinos y autoridades. ${ }^{26}$

La iglesia se encontraba en las inmediaciones de la Matriz «sobre la barranca del río y hacia el norte de la plaza de armas» y, como hemos consignado anteriormente, volvió a ocupar idéntica posición en el nuevo sitio de la ciudad. ${ }^{27}$ Sus promotores pudieron ver acabada su edificación en el primer emplazamiento santafesino gracias a la intermediación de las autoridades del cabildo de la ciudad, que en 1618, anticipándose a la visita diocesana, se manifestaron más preocupados en la conclusión de su obra que en solucionar problemas similares en la Iglesia Matriz.

Mientras que nada se resolvía en cuanto al reacondicionamiento de la iglesia mayor, pues se aguardaba el arribo del obispo Pedro de Carranza para consultarlo, los cabildantes acordaron solicitar al cura vicario tejas para el templo de San Roque que se costearían con recursos particulares del Gobernador. ${ }^{28}$ Luego

\footnotetext{
${ }^{24} \mathrm{El}$ culto popular al santo de Montpellier se extiende en el siglo XVII compitiendo con las exaltaciones de San Adrián y la más universal de San Sebastián, igualmente protectores de las pestes con quienes suele estar acompañado San Roque en las representaciones iconográficas. Aunque el conjunto más vasto de expresiones devotas ha sido localizado en Francia y en Italia, la veneración al santo «abogado para los contagios y pestes» se manifestó tanto en la península ibérica como en América donde comenzaron a dedicarle iglesias y oratorios desde mucho tiempo antes a su canonización concedida por Urbano VIII en 1629. Sobre la vida del santo y la divulgación de su culto pueden consultarse M. Herrero García, «San Roque» en Año Cristiano, Tomo III, Madrid, 1959, pp. 407-410; N. SALOMÓN Lo villano en el teatro del Siglo de Oro, Madrid, 1985, pp. 192-214; C. LEONARDi, A. RiCCARDI y G. ZARRI (directores) Diccionario de los santos, T II, Madrid, 2000, pp. 1998-2001.

${ }^{25}$ El presbítero Strina menciona un auto eclesiástico del año 1606 que no hemos podido localizar, mediante el cual se autorizó la erección de una ermita conjunta a San Sebastián y a San Roque. Sostiene sin embargo, en alusión a la celebración de una rogativa que, en esta ya no se lo nombra porque «los santafesinos habían decidido dedicarle una iglesia al patrón de los naturales» en R. STRINA (1990) Ibidem, p. 23. 1616.

${ }^{26}$ AGSF, Actas de Cabildo, Tomo I Segunda Serie, f. 70v-f. 71. Santa Fe, 12 de Septiembre de

${ }^{27}$ A. Zapata Gollán (1990) Ibidem p. 32. Las «tres iglesias» a las que se refiere el autor en el artículo citado son las de San Francisco, Santo Domingo y la Merced, ya que la de San Roque, la Matriz y la iglesia y convento de la Compañía de Jesús fueron arrasadas por la crecida del río Quiloazas (hoy San Javier).

${ }^{28}$ AGSF, Actas de Cabildo, T. I Segunda Serie, f. 162v- f. 16. Santa Fe, 1 de Enero de 1618.
} 
del traslado, ya en Santa Fe de la Vera Cruz, volvió a edificarse -siempre precariamente- la iglesia de San Roque «jurado de esta ciudad» ${ }^{29}$ y la tarea concluyó en el año 1674 con los aportes «que por su devoción y a su costa» hizo el alférez real y alcalde ordinario, capitán Francisco Moreyra Calderón. ${ }^{30}$

No interesa aquí la reconstrucción fáctica de la obra edilicia, sino seguir las huellas documentales más antiguas que, aún refiriéndose exclusivamente a este aspecto de su existencia, nos acercan tanto a los modos de participación de vecinos y autoridades como a los términos que utilizaron para reseñar este santificado lugar, nombrar a los ministros a cargo, a sus feligreses y a las actividades que los convocaban. Estos datos resultan entonces, importantes indicios para el conocimiento de las funciones y las formas institucionales que fue adquiriendo la iglesia de San Roque.

La primera mención respecto de su feligresía, esto es que estaba destinada a «los naturales», se encuentra en el acta capitular de una sesión de 1618 en la cual estuvo presente el gobernador Hernando Arias de Saavedra, quien se comprometió a sufragar los gastos de su fábrica. ${ }^{31}$ Desde entonces proliferaron las celebraciones solemnes y otras prácticas relacionadas a la iglesia como la que fue registrada en el año 1652. En esta fecha otras especificaciones de sus condiciones de existencia sugieren una configuración institucional similar a la que adquiere, más palmariamente, en el siglo XVIII: la de «parroquia de naturales». El mismo día de elección de los oficios capitulares, y en conformidad y por costumbre antigua, se designaron los mayordomos de los santos patronos y en el acta de esta sesión el notario consignó:

«siguiendo la antigua costumbre y devosion devida por este Cavildo y siudad a los bien abenturados san jerónimo y san marselino cuyas ymajenes estan colocadas en la yglecia mayor desta ciud y san rroque parroquia de los naturales se elijan mayordomos para el servicio dellas y sus cofradias».32

Que la iglesia de San Roque fuera «parroquia de naturales» implica que se trataba de un ámbito eclesiástico institucionalizado y definido jurisdiccionalmente de acuerdo con la organización de los territorios diocesanos. Este aspecto fundamental de la configuración parroquial de San Roque que en otros

${ }^{29}$ AGSF, Actas de Cabildo, Tomo IV, f. 148v- f. 150. Santa Fe, 15 de Octubre de 1663.

${ }^{30}$ AGSF, Actas de Cabildo, T IV, f. 322v-f. 323v, Santa Fe, 5 de enero de 1674.

${ }^{31}$ AGSF, Actas de Cabildo, T. I Segunda Serie, f. 162v- f. 16. Santa Fe, 1 de Enero de 1618.

${ }^{32}$ AGSF, Actas de Cabildo, Tomo III B, f. 261v -f. 263.Santa Fe, 29 de Abril de 1652. Se designó al alcalde primero como mayordomo del patrón San Jerónimo, al alcalde segundo de San Marcelino, y al regidor para la mayordomía de San Roque. Esta distribución de las mayordomías respecto de los oficiales a cargo, al menos hasta donde alcanza esta investigación, continuó hasta finales del XVIII.(El destacado es nuestro).

Hispania Sacra, LXIII

128, julio-diciembre 2011, 433-467, ISSN: 0018-215-X 
estudios había sido pasado por alto ${ }^{33}$ pudo observarlo Stoffel, el primero en advertir que el caso santafesino se ajustaba relativamente a lo ordenado en el II Concilio Limense (1567-1568), en el cual se mandaba que:

«... en los arrabales de pueblos de españoles se pongan parroquias de indios para los que moran entre españoles, y no se señalen mas de quatrocientos parroquianos a un cura, y aún con este número se debe tener y asegurar conciencia de los que tienen obligación de asegurarle doctrina...» ${ }^{34}$

El historiador eclesiástico, observó:«Estas Parroquias eran verdaderamente tales, en el espíritu que pretendía Trento y contaban con una jurisdicción territorial propia dentro de un Obispado, con su iglesia propia (sic), pila bautismal y reserva del Santísimo Sacramento, un Párroco y una feligresía compuesta por naturales». 35

Si bien las tareas pastorales se definían en el entramado jurídico canónico, la normativa monárquica bajo el ejercicio del Patronato Real proporcionó el bastimento de esta configuración eclesial. Las decisiones de la Corona -con las sucesivas provisiones y reales cédulas- así como la preceptiva de las autoridades diocesanas -con las normativas conciliares y sinodales-36 y las prácticas de los agentes laicos y eclesiásticos en cada espacio, ponen en evidencia las continuas readaptaciones a las especiales condiciones que también en el orden de las construcciones institucionales desembocaron en la formación de mundos nuevos en el Nuevo Mundo. ${ }^{37}$

\section{EL ORDENAMIENTO DE LOS TERRITORIOS DIOCESANOS. LA ADECUACIÓN DEL MODELO}

El curato o parroquia es una unidad de organización diocesana que podemos definir como institución en la medida que comparte las características que genéricamente definen esta última noción, es decir,

\footnotetext{
${ }^{33}$ R. StrinA, «Iglesia del Señor San Roque Parroquia de Naturales». Ra, año LXXXIX (1990) 2032; FAsolino, Nicolás «Instituciones religiosas en Santa Fe» en Historia de las Instituciones de la Provincia de Santa Fe, Tomo III, 1970.

${ }^{34}$ R. VARgas Ugarte, Concilios Limenses (1551-1772), Lima, 1954, p. 235. citado en E. STOFFEL «Los curatos santafesinos en la época colonial», Idem.

35 E. STOFFEL, Idem.

36 A. GARCÍA Y GARCÍA, «Organización territorial de la Iglesia», en P. BORGES MORAN -coordinador- Historia de la Iglesia en Hispanoamérica y Filipinas, Tomo I, Madrid, 1992, p. 152; «Las asambleas jerárquicas», Ibidem, pp. 186-188.

${ }^{37}$ G. Boccara, Colonización, resistencia y mestizaje en las Américas (siglos XVI-XX), 2002, p. 7.
} 
«una ordenación parcial de la vida del hombre en sociedad que ha llegado a un desarrollo sólido y autónomo a través de la actividad desplegada y la renovada adhesión de muchas generaciones». ${ }^{38}$

Durante el Antiguo Régimen, la parroquia se estableció como un elemento de primer orden para la fijación de los territorios de la Monarquía Hispánica. Por la estabilidad que en larga duración han tenido su denominación y su territorio, la misma ha proporcionado a los historiadores uno de los marcos de referencia más estables para localizar pequeñas comunidades dentro de jurisdicciones más vastas. ${ }^{39}$ El Concilio de Trento (1545-1564) suministró al establecimiento parroquial un significativo impulso como organización comunitaria apta para la cura de almas $\mathrm{y}$, si bien esto no significó un abierto pronunciamiento por este principio territorial como criterio exclusivo para la organización pastoral, es claro que los decretos conciliares promovieron esta territorialización. ${ }^{40}$ La cúpula de las jerarquías diocesanas en los territorios americanos han dado señales de la amplia y duradera recepción que tuvieron estos lineamientos tridentinos, de lo cual, además de las resoluciones del II Concilio Limense -y también las del III Limense (1582-1583) - constituyen una prueba. ${ }^{41}$

Si devolvemos los latidos de la vida a este armazón jurídico, la parroquia era la comunidad de fieles cuyo cuidado pastoral -cura animarum- bajo la autoridad de un obispo o prelado, se confiaba a un párroco. ${ }^{42}$ En la Península, la feligresía constituía el vecindario parroquial y, al ser sus miembros sujetos del gobierno civil y eclesiástico, sobre la mejor y más sana parte de los habitantes acabó por instituirse dos identidades convergentes: feligreses y vecinos. Esta asimilación, sin embargo, no excluía de la feligresía a quienes no adquirían el estatuto de vecindad y, toda vez que se tratara de fieles cristianos católicos, la parroquia era un ámbito de convivencia de vecinos, moradores y forasteros.

38 V. TAu AnzoÁtegui, «Las Instituciones» en V. TAu AnzoÁtegui y E. Martiré Manual de Historia de las Instituciones Argentinas, Buenos Aires, 2005. [7ª edición], p. 36.

39 «Toute communauté rurale tend à se territorialiser: la religion joue un grand rôle dans le processus et dans la conservation des limites...De façon assez générale, le territoire de la parroisse est identique a celui de la commune», G. LE BRAS, L'eglise et le village, París, 1976, pp. 89-90. Lo mismo se sostiene para Portugal en A. M. HesPanHA, Vísperas de Leviatán. Instituciones y poder político (Portugal, siglo XVII), Madrid, 1989, p. 61 .

40 A. VIANA, «La doctrina postridentina sobre el territorio separado, nullius dioecesis», Ius Canonicum, XLII, 83 (2002) p.44. J. LARRABE, «La creación de nuevas parroquias según el Concilio de Trento», en Teología T I, 3 (1963); J. LARRABE, «Las nuevas parroquias. Doctrina Conciliar de la Iglesia», Studikum, 1969, p. 58.

${ }^{41}$ A. Bunge, «Notas sobre el III Concilio Provincial de Lima (1582-1583). El régimen parroquial», en Teología, T XVII, 36, p. 159 y ss.; N. SuÁrEZ, «La Parroquia eclesiástica colonial. Bases constitutivas. El caso de San Buenaventura de Ejido», Presente y Pasado, Año X, Vol.10, 19 (2005) 44-64.

42 Cfr. voz parroquia en M. Teruel Gregorio de Tejada Vocabulario básico de Historia de la Iglesia, Barcelona, 1993, pp. 297-311.

Hispania Sacra, LXIII

128, julio-diciembre 2011, 433-467, ISSN: 0018-215-X 
En este punto es donde la experiencia americana respecto a la configuración institucional de la feligresía asoma con su especificidad. Cuando aquí se considera el aspecto institucional de esta configuración parroquial, se lo concibe en el marco un sistema de vigencias, en el que cada institución funciona con un conjunto de fuerzas en estado de tensión que «incitan al hombre a buscar en ellas el libre juego de sus posibilidades». ${ }^{43} \mathrm{El}$ factor que incidió decisivamente en las particularidades que ofrecía el laboratorio americano para concretar estas instituciones en un régimen de unanimidad religios ${ }^{44}$ fue la condición étnica -devenida social- de los sujetos de la empresa de conversión a la fe.

En virtud de estas condiciones, la inicial tarea de evangelización agenciada por el clero regular derivó en muchos casos en la asunción del cuidado parroquial. Por otra parte, mientras en los territorios peninsulares el término parroquial coincidió en gran medida con el término político del concejo, en los territorios americanos esta coincidencia institucional no se manifestó sino muy excepcionalmente. ${ }^{45} \mathrm{Y}$, por último, la utilización y resignificación de los vocabularios en un ambiente crecientemente mestizo cobró dimensiones que aún no han sido estudiadas.

Precisamente, esta problemática invade el tema que aquí se aborda, ya que desde el mismo uso del término «natural» para identificar a la feligresía de una configuración parroquial tan singular plantea interrogantes acerca de la «naturaleza» como categoría de pertenencia en los reinos de la Monarquía Hispánica.

\footnotetext{
${ }^{43}$ Cfr. V. TAu AnZoÁtegui Ibidem, p.33.

${ }^{44} \mathrm{Al}$ respecto puede consultarse R. DI StEFAnO y L. ZANATTA, Ibidem, p.18.

45 Para el caso de la capital novohispana, Sánchez Santiró ha analizado la composición tripartita de la capital virreinal, conformada por dos ciudades prehispánicas -Tenochtitlan y Tlatelolco-, y la ciudad española incrustada entre ambas -México-, en la división eclesiástica plasmada en cuatro doctrinas y una parroquia fundamentaba los principios de separación territorial en un ente político constituido por la república de españoles y la república de indios; en E. SÁnchez SANTIRó Idem. Algunos casos en el Río de la Plata: de acuerdo con Ayrolo, en 1806, el cabildo de La Rioja contaba, además de la matriz en la ciudad principal, con cuatro curatos o parroquias (Los Llanos, Guandacol, Famatina y Arauco, cada uno con sus comunidades de indios) ver V. AYROLO (2005) Idem; La configuración curatal del cabildo de Córdoba tampoco se ajustó al esquema ibérico, ver en particular el cuadro compuesto por Valentina Ayrolo en Funcionarios de Dios y de la República, Buenos Aires, 2007, pp. 27-28; también las referencias proporcionadas en A. I. PunTA, Córdoba borbónica, Córdoba, 2010 [2a . edición]. Acerca la jurisdicción cuyana -que hasta 1806 dependieron del obispado de Chile-el cabildo de Mendoza y las tres parroquias matrices y siete rurales que existían en 1785, consultar O. PELAGATTI, «La transformación del espacio eclesiástico en el Virreinato del Río de la Plata a principios del siglo XIX: el intento del obispo de Cuyo» en G. CARETTA y I. ZACCA (compiladoras) Ibidem, pp. 243-262. En Cochinoca -Jujuy- Enrique Cruz analizó las relaciones entre el curato, el cabildo indígena y el cabildo secular de Jujuy; en E. N. CRUZ, «Poder y relaciones sociales en curatos de indios. El curato de Cochinoca en el siglo XVIII (Puna de Jujuy-Argentina)», Hispania Sacra 117 (2006) 355-381, p. 358.
} 
La noción de natural para designar el origen de los súbditos del rey registra orígenes medievales ${ }^{46}$ y su vigencia en los ordenamientos jurídicos de los siglos modernos lejos de contribuir a clarificar su significado ha provocado la imprecisión de su definición; ${ }^{47}$ siendo una de las manifestaciones más claras la coexistencia de un sentido de horizontalidad de las relaciones entre naturales como miembros de la comunidad local y la tendencia a equiparar naturaleza con vasallaje, como relación de verticalidad entre el rey la comunidad del reino. ${ }^{48}$

Herzog señala que la idea moderna de «naturaleza», desplazó el lugar de nacimiento como factor determinante ligándose más estrechamente a la categoría de vecindad ${ }^{49}$-definida desde y por el lugar de residencia- y que esta identificación fue, más acusada en Hispanoamérica que en la Península. Sin embargo, los «naturales» de la feligresía que aquí se estudia, nunca alcanzaron el estatuto de «vecinos». No se dispone aquí de una explicación acabada ni del espacio suficiente para el desarrollo que amerita este tema, sí pueden relevarse algunos usos admitidos en el corpus documental de base para este análisis.

Un primer uso es el que adopta como factor determinante de la «naturaleza» el lugar de nacimiento: «naturales» hace referencia a la población nativa. Asimismo, en los registros parroquiales los feligreses negros, mulatos, pardos o mestizos, suelen contener especificada la situación de «natural», como indicativo de origen: «Negro esclavo de Dn Ignacio Aguiar, natural de Loango», «Parda libre natural de Lisboa», «Negro esclavo, criollo de río de Geneiro, natural de Río Grande». .0

Ahora bien, en estos mismos registros aparecen otros usos del término «natural» construido desde la perspectiva de la comunidad local que reconoce localizaciones más precisas o connota el vínculo existente con la ciudad: «Indio viudo natural del pueblo de San Carlos», «India (...) natural del Pueblo de San Cosme», «Indio (...) natural del Pueblo de Santiago en las Misiones», «India natural de Buenos Aires, forastera y de otra tierra». ${ }^{51}$

46 L. G. Valdeavellano, Curso de historia de las instituciones españolas, Madrid (1968), pp. 413-438.

${ }^{47}$ M. I. CARZOLIO, «Cuándo y por qué. La ocasión de la concesión de naturaleza en el siglo XVII», en M. L. GonzÁlez MEZQuita (compiladora) Estudios de historia moderna: contextos, teorías y prácticas historiográficas, Mar del Plata (2007), 359-380. De acuerdo con la autora aunque en la Nueva Recopilación (1640) la noción de naturaleza adquiere definiciones más claras, pero aun en el siglo XVIII la misma presenta perfiles imprecisos.

48 T. Herzog, Vecinos y extranjeros. Hacerse español en la Edad Moderna, Madrid (2006), 29.

${ }^{49} \mathrm{La}$ vecindad implicaba el disfrute de unos derechos de parte de una minoría, mientras se cumpliera con una serie de requisitos y unas obligaciones fijadas por la comunidad local. La construcción de la identidad de vecino definía su contraparte: el forastero.

50 AHASFVC, Libro de información matrimonial, VII, 1756-1761.

51 AHASFVC, Libro de información matrimonial, VII, 1756-1761.

Hispania Sacra, LXIII

128, julio-diciembre 2011, 433-467, ISSN: 0018-215-X 
En relación a estas descripciones debe apuntarse un aspecto que equipara y otro que distingue a los feligreses del curato de naturales de los indios cristianizados de las reducciones o pueblos de indios: en ambos casos se operaba una «desnaturalización» en el sentido de desarraigo de las comunidades indígenas ${ }^{52}$ pero, mientras los últimos fueron trasladados masivamente e incorporados con sus familias y en grupos más extensos a la vida cristiana, la feligresía de naturales estaba compuesta de gentes desvinculadas de sus comunidades de origen y residentes en un ámbito de dominación diferente: en el ejido urbano o muy próximas a él, en las chacras o en la casa de sus señores -en ocasiones también la de los mismos clérigos o religiosos.

En la ciudad y en esas casas pudieron formar familia pero, generalmente, habían sido conducidos solos o con una familia desmembrada. Indios e indias cautivas, derivados de una encomienda, yanaconas en servicio doméstico, jornaleros o esclavos y esclavas, en el caso de negros o mulatos, comenzaban a partir de estas condiciones de residencia, una nueva dinámica relacional y la integración a la comunidad urbana.

Todo indica que en esa dirección el primer paso era el catecismo, pues, en muchas informaciones, añaden a la identificación de quien solicita servicios religiosos que, amén de ser indio, negro, de tal origen y residir desde tal fecha, en casa de tal o cual señor o señora, son «catecúmenos», luego, la conversión a través del sacramento del bautismo permitía la «naturalización» de los gentiles por el nacimiento a la fe.

Una vez catequizados, bautizados e imbuidos de hábitos cristianos, los indios pasaban a considerarse «naturales» y a integrar la feligresía pero, así como se dijo que la condición de «naturales» que los hacía feligreses no los convertía en «vecinos», tampoco la calidad de feligreses naturales era idéntica a la de los feligreses españoles y criollos.

Esta diversidad étnica de la feligresía condicionó las formas institucionales previstas en el ámbito de la Cristiandad europea y el modo en que una sociedad como la antiguo regimental -elosa de las jerarquías, preservadora de los estamentos y estigmatizadora de las castas- resolvió su integración mediante la configuración parroquial, impidió en territorios americanos la combinatoria: una parroquia un cabildo.

$\mathrm{Al}$ igual que el desajuste entre otras jurisdicciones eclesiásticas y seculares que la administración monárquica intentaba salvar, también se persiguió el aco-

52 Análisis de casos sobre políticas de desnaturalizaciones M. A. PALERMo y R. BoIXADós «Transformaciones en una comunidad desnaturalizada: los Quilmes, del Valle Calchaquí a Buenos aires» Anuario del IEHS, VI (1991), 13- 42; J. FARBERMAN y R. BoIXADós «Sociedades indígenas y encomienda en el Tucumán colonial. Un análisis comparado de la visita de Luján de Vargas» Revista de Indias 248 (2006) 601-628. 
modamiento de la jurisdicción parroquial. Felipe II, en la ordenanza número 4 del Consejo de Indias, y Felipe IV, en la número 7, del año 1636, habían prescripto «que el estado del Indias esté dividido de modo que en lo temporal se corresponda con lo espiritual» y en la Recopilación (1680) se recogió que:

«la división en lo temporal se vaya conformando y correspondiendo cuanto se compadeciere con lo espiritual; los arzobispados y provincias de las religiones con los distritos de las audiencias; los obispados con las gobernaciones y alcaldías mayores; y parroquias y curatos con los corregimientos y alcaldías ordinarias». .3

Pero esto no se definió sino muy tardíamente ${ }^{54}$ y las configuraciones institucionales bajo las cuales se concretaron las agencias eclesiales dirigidas a la atención de esas feligresías diferenciadas, ambas dentro de los términos jurisdiccionales del cabildo, sumó complejidad al esquema utilizado en territorios ibéricos. La convergencia de las tareas pastorales del clero secular, al cual tradicionalmente el derecho canónico les concedía el lugar de preferencia en la provisión de parroquias y curatos, con la de los religiosos y frailes doctrineros que ingresaban a la órbita de la autoridad episcopal, además de sumar motivos a la conflictividad connatural a cualquier comunidad, suministró complejidad a los vocabularios para nombrar estas realidades.

Así, de las relaciones que el clero estableció con el mundo indígena, surgieron configuraciones eclesiásticas denominadas con fórmulas que, aun cuando tienen un aire de familia que favorece el confundirlas o pensarlas como intercambiables, pueden referir a realidades y modos de funcionamiento disímiles. Las más difundidas son doctrina de indios, parroquia de indios, curato de naturales y/o curato de indios, lo cual motiva una sumaria indagación acerca de este tipo de formaciones y de las definiciones de los términos utilizados para dar cuenta de ellas.

\section{PARROQUIAS O DOCTRINAS. PÁRROCOS Y CURAS DOCTRINEROS}

Hay quienes han visto en las doctrinas el resultado evolutivo de las tareas misionales. García, por ejemplo afirma que «Las misiones o centros misionales solían convertirse en Doctrinas o Parroquias de indios después de diez o veinte años, según las diferentes épocas y zonas, de iniciada la evangelización de un territorio». ${ }^{55}$ Lo mismo afirma Wilde, quien sostiene que, mientras «reducción»

${ }^{53}$ Recopilación de las Leyes de los Reinos de las Indias, lib. II, tít.II, ley 7. Boix, [5ª . edición] Madrid, 1841, p.155. (en adelante Recopilación).

54 V. Ayrolo (2007) Ibidem, «El dibujo de la provincia-diócesis», 21-46.

55 A. GARCíA y GARCíA, «Organización territorial de la Iglesia», en P. Borges Moran, Ibidem, 146. 
o «misión» aluden a «establecimientos o poblados formados con gente en proceso de conversión al cristianismo», las doctrinas o parroquias de indios refieren a instancias de administración religiosa en grupos más estabilizados. ${ }^{56}$

Como vemos, el intento de definición deja otra cuestión a dilucidar ¿qué elementos o condiciones diferencian a una doctrina de una parroquias de indios?

Si se siguen las explicaciones de García, tanto en las parroquias de indios como en las doctrinas, los indios convertidos recibían «los mismos cuidados pastorales que los demás fieles en las parroquias de tipo tradicional» y por ello a muchos se los llamaba párrocos. ${ }^{57}$ Idénticas en su finalidad y servicios pastorales, la doctrina y la parroquia, no obstante, representaban dos instancias jurídicamente diferenciadas.

Las condiciones bajo las cuales estos doctrineros llamados párrocos ejercían su ministerio no siempre se ajustaban al principio del derecho canónico de acuerdo con el cual el beneficio constituía el elemento definitorio de la institución parroquial. Como señala el autor «se dio con frecuencia el caso de que los doctrineros o párrocos de indios no poseían el cargo a perpetuidad o, como se decía en términos más técnicos, no tenían un beneficio parroquial perpetuo». ${ }^{58}$

Por el contrario las leyes de Indias que habilitaban el acceso de los doctrineros al sistema beneficial, propiciaban la diferenciación de los términos. En la reglamentación del orden a seguir en la provisión de beneficios curados se mandaba que:

«vacando [...] cualesquier beneficios curados, asi en los pueblos de españoles como de los indios, que se llaman doctrinas, los obispos y los arzobispo en cuyos distritos vacaren pongan edictos públicos para cada uno».59

En la norma, el criterio de diferenciación sigue los fundamentos de la segregación étnica que pervive en definiciones actuales ${ }^{60} \mathrm{y}$, de hecho, en algunas zonas, esto ha podido ser verificado.

Para el caso de la ciudad de México, Sánchez Santiró ha observado que hasta los años 1760 hubo un «uso étnico», antes que jurídico, de los términos parroquias y doctrinas, en la medida que se hablaba de estas «con base en las distintas feligresías que las componían, españoles, mestizos, mulatos, etcétera,

\footnotetext{
${ }^{56}$ G. WILdE Religión y poder en las misiones guaraníes, Buenos Aires, 2009, nota 1, 389.

${ }^{57}$ A. GARcía Y GARCíA, Idem.

58 Idem.

${ }^{59}$ Recopilación, lib. I, tít.IV, ley XXIV. El resaltado es nuestro.

${ }^{60}$ Hay quienes refieren que las parroquias eran pequeños distritos de «población española» asignados a una iglesia a cargo del cura párroco; V. TAU AnzoÁtegui y E. MartiRÉ, Ibidem 229.
} 
e indios, respectivamente». ${ }^{61}$ Estas experiencias exponen el diversificado panorama de las configuraciones parroquiales americanas.

En el Río de la Plata, según lo ha indicado Di Stefano, algunas sedes parroquiales albergaban a dos párrocos, cada uno con sus respectivas feligresías: «el de españoles, cura de blancos, negros y castas, y el de naturales, cura de indios».62 Durante la gestión del obispo fray Cristóbal de Mancha y Velazco se instituyeron parroquias de naturales en ámbitos muy diferenciados. En 1646, la parroquia de San Juan Bautista de naturales se erigió en el mismo casco urbano de Buenos Aires donde parece no haber precedido otra institución y con el propósito de que «los indios que habitaban en la ciudad fueran evangelizados por un sacerdote nombrado para ellos especialmente y se encargara de su cristianización».63

En 1648, en visita diocesana y como fiel ejecutor del Real Patronato, el obispo concedió a las iglesias de las reducciones y pueblos de indios, a cargo de la Compañía de Jesús, la institución canónica de parroquia y señaló por feligreses a los indios avecindados en ellas. El procedimiento, acorde a la línea de desarrollo advertida en las definiciones de Wilde o García y García, fue explícito en el auto de erección ya que expresó que «no haviendo hallado cosa que reformar, sino tantas almas de nuevo convertidas a Dios» otorgaba licencia para administrar sacramentos a los religiosos jesuitas que estaban a cargo de la reducción. ${ }^{64}$

La autoridad real ratificó por Cédula de 15 de junio de 1654 las providencias episcopales, sancionando que:

«...han de ser Doctrinas y se han de tener por tales las que llaman reducciones y misiones los Religiosos de la Compañía de Jesús que residen en la provincia del Paraguay y que en todas ellas hayan de presentar para cada una tres sujetos, de los cuales el gobernador nombre uno estando advertidos los dichos Virreyes, Presidentes, Gobernadores, Arzobispos, y Obispos que si la dicha Religión no se allanare al cumplimiento de esta orden, en cualquiera parte del gobierno de cada uno han de disponer se pongan clérigos seculares y, en falta de ellos, Religiosos de otras órdenes en las tales doctrinas, porque no han de quedar en su libre voluntad lo que fuere contra derecho de mi Real Patronato...»65

${ }^{61}$ E. SÁNCHEZ SANTIRó, Ibidem, p. 67.

${ }^{62}$ Roberto Di STEFANO; Loris ZANATTA, Historia de la Iglesia argentina, cit., 61-62.

${ }^{63}$ E. SALVIA, «La creación de parroquias en la iglesia particular de Buenos Aires. 1ra parte. Desde la Colonia hasta 1923», Buenos Aires, 2003. Disponible en http://www.historiaparroquias.com.ar/document.php

${ }^{64}$ F. Actis, Actas y documentos del cabildo eclesiástico de Buenos Aires, T.II, Buenos Aires, 1944, p. 17.

${ }^{65}$ Ibidem, 20.

Hispania Sacra, LXIII

128, julio-diciembre 2011, 433-467, ISSN: 0018-215-X 
Sin embargo, la concesión de colación y canónica institución de los curas doctrineros, gestionada ante el Consejo Real y el Obispo por los prelados de las religiones, generó encendidos debates en el obispado de Buenos Aires.

En el año 1666, frente a la necesidad de proveer la doctrina del Pueblo de indios Quilmes, el Rector de la Compañía de Jesús en Buenos Aires solicitó al presidente del Real Consejo la colación y canónica institución para los religiosos. ${ }^{66}$ Remitida la solicitud al obispo, éste observó que dar curato en propiedad a la Compañía significaba «cerrar la puerta a que haya clérigos al servicio del Culto divino» y también que esa determinación impugnaría lo ordenado por el Real Patronato y el Santo Concilio de Trento, en el cual tampoco estaba establecida una colación canónica condicional ni confidencial como reclamaba el Rector. ${ }^{67}$

El obispo de la Mancha y Velasco calificó esta demanda como una reprobable apetencia muy contraria a la misión de los jesuitas, concluyendo que de no cumplir estos lo ordenado por sus votos, por los decretos tridentinos y el Real Patronato: «se conocerá claramente que quieren el curato de los Quilmes y no la salvación de las almas». ${ }^{68} \mathrm{El}$ presidente del Real Consejo comunicó al Rector que conforme a lo expuesto por el obispo y a otros ordenamientos determinaba que «la Compañía acuda al fruto de las almas de los Indios Quilmes sin la calidad de curato». 69

En la campaña bonaerense, Barral observó que durante el proceso de consolidación institucional diocesana iniciado hacia 1730 con la instauración de nuevas parroquias, hubo casos en los que algunas de las sedes parroquiales debieron fijarse interinamente en «iglesias de pueblos de indios». ${ }^{70}$ De acuerdo al edicto de erección de nuevos curatos, efectivamente, en el pago de Magdalena la parroquia funcionaría en la Iglesia de Santa Cruz de los Quilmes y en el pago de Arrecifes en la iglesia del Pueblo de Indios, Santiago de Baradero. Pero en el deslinde de jurisdicciones no siempre se conservaron las preexistentes. Mientras que en los pagos de Magdalena y de Arrecifes los pueblos de indios fueron incorporados al curato de españoles, en otros consta que la nueva asignación de términos parroquiales resguardó aquellos que pertenecían a los curatos de naturales.

En el pago de Matanza, por ejemplo, se concedió a la nueva parroquia «todo el territorio qe comprehende esepto una legua del qe empieza desde los obrajes

\footnotetext{
${ }^{66} \mathrm{~F}$. ACTIS, Ibidem, 105.

${ }^{67}$ F. Actis, Ibidem, 108 y p. 115.

68 F. ACTIS, Ibidem, 109 y 120.

${ }^{69} \mathrm{~F}$. Actis, Ibidem, 123.

${ }^{70}$ Cfr. María Elena BARRAL, «Las parroquias rurales de Buenos Aires entre 1730 y $1820 »$, Andes, núm. 15, Salta, 2004.
} 
de materiales inmediato a esta $\mathrm{Ciu}^{\mathrm{d}}$ exclusive la qual aplicamos al curato de naturales della». ${ }^{71}$ Esto mismo consta para el curato del pago de la Costa o Monte Grande e incluso la jurisdicción del curato de naturales de la ciudad de Buenos Aires fue modificada por este edicto.

Un año más tarde, como parte del mismo proceso, el obispo de Buenos Aires fray Juan Arregui y el gobernador como vicepatrono, crearon los curatos rurales de San José de Saladas y Empedrado y dividieron el curato rectoral de Corrientes en dos parroquias, una para españoles y otra para naturales. ${ }^{72}$

En una carta del obispo Juan de Sarricolea al rey informaba que, de acuerdo a la visita del año 1729 en su diócesis de Córdoba del Tucumán, la misma contaba con 9 curatos de españoles que residen en las siete ciudades y 26 curatos de naturales. ${ }^{73}$ En el distrito de Jujuy, de acuerdo con la definición de Cruz, estos últimos curatos constituían la base del ordenamiento del ejercicio de la evangelización, de los deberes políticos, de las funciones públicas y de los servicios administrativos, una «Circunscripción de tipo eclesiástica que tiene su origen en la doctrina de indios tributarios». ${ }^{74}$

Estos datos confirman la existencia de modalidades diferenciadas de constitución de curatos de naturales en diferentes zonas del Río de La Plata a lo largo de los siglos XVI, XVII y XVIII, pero la información no siempre es precisa acerca del clero a cargo ni de sus dinámicas de funcionamiento. Así por ejemplo, en su análisis del curato de indios de Cochinoca en Jujuy, Enrique Cruz señala que «el ejercicio del poder religioso en curatos rurales de población mayoritariamente indígena, fue desarrollado en los distritos andinos del virreinato del Río de la Plata por los 'curas doctrineros'». 75

Si bien podemos colegir que se trataría de curas pertenecientes al clero secular, la información volcada en ese trabajo no permite asegurar la existencia de una relación de estos con el sistema beneficial, ni la del vínculo del otro com-

${ }^{71}$ AHASFVC, Autos y Decretos, T.I, f.227. Edicto. Buenos Aires, 30 de octubre de 1730.

72 Cfr. E. J. A. Maeder, Historia económica de Corrientes en el periodo virreinal, 1776-1810, Buenos Aires, 1982, p.170. El autor cita el auto episcopal del 4-XI-1731 y la aprobación de parte del gobernador Bruno Mauricio de Zabala del 23-XI-1731. El 30 de Julio de 1740 se publicó un edicto de oposiciones al curato de naturales de Corrientes en AHASFVC, Libro de Oposiciones-Edictos y AutosInmunidades (1721-1780/1753/ 1722-1782), f.26r-26v.

73 A. Larrouy, Documentos del Archivo de Indias para la historia del Tucumán, núm. 3, vol. 2, 1927, p. 47. Carta del obispo Juan de Sarricolea dando cuenta de la visita de su diócesis. Córdoba del Tucumán 20 de abril 1729. Para el año 1778 Gabriela Caretta contabiliza, en las jurisdicciones de los 7 curatos rectorales de las ciudades de Córdoba, Catamarca, Salta, Tucumán, Santiago del Estero, La Rioja y Jujuy, la suma de 39 curatos rurales de los cuales no especifica si se trataría de curatos de naturales. Ver el cuadro compuesto por esta historiadora en G. CARETTA (1999) Ibidem, 86.

${ }^{74}$ E. N. CRUZ (2006) Ibidem, 358.

75 Ibidem, p. 355. 
ponente socioétnico de esa feligresía «mayoritariamente indígena» con los indios feligreses.

Por su parte, en otro espacio de la diócesis de Córdoba del Tucumán, en un curato ubicado en jurisdicción del cabildo riojano, Valentina Ayrolo observa sobre su titular: «Pese ser cura doctrinero, no lo era exclusivamente de indios, sino más bien sus funciones eran las de un párroco con cura de indios». Probablemente ciertas tareas impuestas al cura durante el periodo en que ejerció su ministerio -debió empadronar a los habitantes del valle de Famatina en los primeros años del siglo XIX-explique que cuando lo hizo «levantó el padrón [...] y realizó su descripción, contó a todos los habitantes de su parroquia sin importar su condición». ${ }^{76}$

Aunque sobrevivieron largo tiempo las polémicas acerca de la entidad de los curas dedicados a doctrinar y administrar sacramentos a los indios, las formas institucionales que adoptaban estos espacios y las consecuentes dependencias jurisdiccionales ${ }^{77}$ a finales del siglo XVIII, prácticamente no existían los curatos de naturales en el Río de la Plata: se había extinguido el de la ciudad de Buenos Aires en 1769, el de Corrientes había visto quebrajada su legitimidad desde 1779 (fue suprimido en 1795) ${ }^{78}$ y el de Santa Fe pereció en 1787.

\section{El curato de naturales de Santa Fe de la Vera Cruz}

Una ligera comparación, con base en la bibliografía, permite observar que el curato de naturales en Santa Fe plantea una diferencia respecto de las parroquias o curatos de indios, mayoritariamente rurales: contó con iglesia propia en sede urbana y exhibe una leve distensión respecto de la composición de su feligresía.

En cuanto al primer señalamiento, en el Río de la Plata sólo se ha podido verificar la existencia de curatos de naturales con sede urbana en las ciudades de Buenos Aires (1646) y de Corrientes (1731), en esta última, puede observarse

\footnotetext{
76 Valentina Ayrolo (2005) cit., p.309. La autora transcribe en el artículo citado el «Padrón de del curato de Santa Rosa de Anguinán, Famatina, La Rioja» del 16 de mayo de 1806 realizado por cura párroco Joseph Nicolás Ocampo.

${ }^{77} \mathrm{Al}$ respecto puede consultarse A. LEVAGGI «Controversia entre el Colegio de San Carlos de propaganda fide en Santa Fe, el Obispo y el Virrey sobre el gobierno de las reducciones de San Jerónimo e Ispín (1795-1803)», en Iushistoria 1, Revista electrónica (2004).

78 Desde 1779 los vecinos solicitaban la creación de curatos rurales y la supresión del curato de naturales. En su visita el obispo Malvar y Pinto acogió con beneplácito el pedido del cabildo pero las nuevas parroquias demoraron en establecerse y el beneficio del cura de naturales se suprimió recién en 1795 por una resolución del obispo Azamor y Rodríguez que suscitó un sonado conflicto. Cfr. E. MAEDER, Ibidem, 174 y nota 110, 177.
} 
que se instaura en una fecha acusadamente más tardía respecto de las mencionadas.

Hay algo que resaltar también en lo referente a la estipulación de una feligresía diferenciada. La escisión parroquial de acuerdo a criterios socioétnicos, no se practicó de manera que el cura de españoles atendiera a los blancos, negros y castas apartando únicamente a los indios de sus servicios pastorales y litúrgicos. A diferencia de lo indicado por Di Stefano, en Santa Fe las autoridades diocesanas precisaron que

«por nombre de Naturales bienen comprehendidos, los hijos de mestiza y de Indio, o al contrario, como también los de India y negro o Mulato». ${ }^{79}$

En esta ciudad la Parroquia de San Roque no se erigió sobre ninguna doctrina preexistente de manera que la denominación de «parroquia o curato de naturales» antes que «parroquia o curato de indios» cobró un particular sentido frente a la simultánea existencia de doctrinas. ${ }^{80}$ Los titulares de su jurisdicción fueron clérigos ${ }^{81}$ que, regularmente a partir del siglo XVIII, accedieron al sistema beneficial por concurso, instituyéndose con la condición jurídica plena de párrocos. ${ }^{82}$ Por lo tanto, la Parroquia de San Roque, a través de la canónica institución de estos beneficios curados, adquirió su condición jurídica plena de curato de naturales, alcanzando así su acrecida institucionalización.

Por esta razón, aunque es significativa la adscripción étnica que connotan determinadas definiciones, en la experiencia santafesina la parroquia de natura-

${ }^{79}$ F. Actis, Ibidem, TII. Acuerdo del 23 de Octubre en q se hizo la divisn. de los Curatos en las jurisdicciones de esta Ciud. y Sta. Fee. 237.

${ }^{80}$ Entre los años 1615 y 1616 Hernandarias fundó las reducciones de San Lorenzo de los Mocoretás, San Miguel de los Calchines y San Bartolomé de los Chanaes. De acuerdo con un informe del año 1627 , la reducción y doctrina de los indios mocoretás, estaba a cargo de Andrés Orona, cura presbítero y las reducciones y doctrinas de los indios chanaes y calchines a cargo de religiosos de la orden franciscana cuyos nombres no se consignan. En F. AcTIS, Actas y Documentos del Cabildo Eclesiástico de Buenos Aires, T. I, *7. Buenos Aires, 8 de julio de 1627. Respuesta a la información solicitada por la Real Cédula fechada en Madrid el 11 de julio de 1625, por mandato del Obispo Pedro Carranza informa el notario apostólico Martín Martínez de Eulate.

${ }^{81}$ No ha sido posible reconstruir la lista completa y las sucesiones de los titulares como se ha procedido para el siglo XVIII pero en ningún caso se trató de religiosos. Los primero localizados en esta investigación: Andrés Fernández Romo (1625-27 aproximadamente); Juan Bautista Centurión (1635, como cura interino de naturales).

${ }^{82}$ Las acciones de los párrocos de San Roque dejaron huellas en diversos repositorios. Sin embargo, sólo contamos un registro más sistemático del funcionamiento del la parroquia de San Roque a partir del siglo XVIII. El corpus de libros parroquiales, edictos y concursos de oposición para cubrir vacantes del curato, informes de las visitas diocesanas y un volumen no menos importante de autos, presentaciones e informaciones que la labor archivística ha compilado en los Libros de Querellas patentizan además del grado de institucionalización de este curato, la importancia de este universo parroquial que se amerita futuras investigaciones.

Hispania Sacra, LXIII

128, julio-diciembre 2011, 433-467, ISSN: 0018-215-X 
les se diferenció de las doctrinas o parroquias de indios, en parte, por la procedencia clerical de los curas a cargo de las respectivas feligresías y su relación con el sistema beneficial, pero en mayor medida por la calificación socioétnica de sus feligreses y la relación de estos con el párroco. ${ }^{83}$

Esta situación instituyente del curato de naturales esquivó los dilemas que afrontaron las doctrinas que atravesaron el proceso de secularización -en especial los conflictos con el clero regular $-{ }^{84}$ aunque, al integrar esta heterogénea y móvil feligresía, la institución se configuró muy conflictivamente respecto de otras del clero secular, en especial con la parroquia de españoles.

Como todavía se recordaba en el año 1814, ambos curatos habían tenido por extensión los mismos términos de la ciudad y su territorio, separado de los partidos de su jurisdicción «...que comprehenden de al N. 25 leguas, al S. los arrabales de la misma, de O. a E. entre el Paraná y Salado de 8 a 9 leguas en el qual se contienen los Pagos del Rincón y Calchines divididos por Los Saladillos [...], el de Azcohingas con las costas del Salado y Añapiré y la Frontera». ${ }^{85}$ Y, según lo aseguraban los cabildantes:

«en todo este territorio han exercido siempre los dos curas igualmente su jurisdicción sin otra división ni límites entre sí que la que tuvieron desde la fundación de la ciudad hasta la reunión de los dos y de sus feligreses en una Parroquia, la qual división solo era respecto de las castas ps el uno solo la de Españoles y el otro de las demas llamado de Naturales» 86

Esta «división» por castas, que subraya en realidad una superposición territorial, ocasionó reiteradas situaciones de pujas entre los sucesivos titulares de ambos curatos que debían recortar los límites del ejercicio jurisdiccional en la

\footnotetext{
${ }^{83}$ Los curas doctrineros, y no los curas de naturales que oficiaron en la ciudad como párrocos de San Roque, son quienes guardan semejanza con aquellos otros curas más insertos en las comunidades indígenas andinas y con una presencia cotidiana en las actividades económicas y sociales de los indios. Estos últimos han sido estudiados, entre otros, por A. ACOSTA «Los clérigos doctrineros y la economía colonial (Lima 1600-1630)» Allpanchis 19 (1982) 117-149; N. SALA I VILA «Algunas reflexiones sobre el papel jugado por la iglesia y el bajo clero en las parroquias de indios en Perú (1784-1812)»en G. RAMos La venida del reino. Religión, evangelización y cultura en América. siglos XVI-XX, Cusco, S. SERULNIKOV Conflictos sociales e insurrección en el mundo colonial andino», en especial pp. 190-214; C. HunEFELDT «Comunidad, curas y comuneros hacia fines del período colonial: ovejas y pastores indomados en el Perú» HISLA 2 (1983) 3-31.

${ }^{84} \mathrm{R}$. AgUIRRE SALVADOR «El establecimiento de jueces eclesiásticos en las doctrinas de indios. El arzobispado de México en la primera mitad del siglo XVIII» Historia Crítica 36 (2008) 14-35; L. PÉREZ PUENTE, «Dos proyectos postergados. El tercer concilio provincial mexicano y la secularización parroquial» EHN 35 (2006) 17-45.

${ }^{85}$ AGSF, Actas de Cabildo, Actas Recuperadas Caja 1, f. 47 v- f. 48 v. Santa Fe, 24 de Septiembre de 1814.

86 Idem.
} 
arena movediza de la distinción socioétnica de sus feligreses. Estos dirimieron acerca de las competencias sobre derechos parroquiales de una feligresía progresivamente mezclada que, captada por el molde conceptual dominante estuvo sujeta a distinciones discriminatorias cada vez más estereotipadas. ${ }^{87}$

Contemporáneamente, la pregnancia de la mezcla condicionó las prácticas de los feligreses que buscaron en la adscripción parroquial una vía para posicionarse socialmente. Aún así, la pertenencia a una u otra parroquia no fue ni una norma cabalmente cumplida ni una opción que se pudiera escoger libremente. En particular, para quienes además de la marca étnica tenían el lastre de la dependencia forzosa -servicio personal y esclavitud- la mediación de patrones o amos incidió categóricamente en la parroquialidad del feligrés, suscitando a veces conflictos entre los párrocos o entre estos y los religiosos de las iglesias de los conventos a los cuales solían acudir las familias notables expresando vínculos y predilecciones con alguna de las órdenes.

\section{PÁRROCOS, FELIGRESES Y GOBIERNO DIOCESANO}

Desde finales del siglo XVII y las primeras décadas del XVIII, como se ha referido, se estabilizaron las condiciones de sucesión en las gestiones parroquiales enmarcándose en los lineamientos jurídicos de la colación y canónica institución de los clérigos de naturales. Desde la titularidad de Tomás de Sala$\mathrm{zar}^{88}$ hasta la extinción del curato de naturales se sucedieron como curas propietarios: Antonio de Oroño, ${ }^{89}$ Pedro Joseph Crespo y Antonio de Vera Mujica. 90

La colación y canónica institución de los respectivos párrocos estuvo precedida por un concurso de oposición ante comisiones de examinadores sinodales y recibieron nombramiento de los respectivos gobernadores como vicepatro-

${ }^{87} \mathrm{Al}$ respecto ver J. H. ELLIOT, «Mundos parecidos, mundos distintos» en G. SALINERO, Mezclado y sospechoso: movilidad e identidades, España y América (siglos XVI-XVIII), Madrid, 2005, p. XVII.

${ }^{88}$ La referencia más temprana de su ministerio es la mención de su nombre en un testamento del año 1693 en el cual impone cuatro capellanías de 500 pesos cada una para 25 misas al año para su alma que debe dar entre otros «en la Parroquia de San Roque, el maestro D. Tomás de Zalazar, presbítero cura de naturales», en AGSF, Libro de Contaduría, T I, 1684-1707, f.19. Asimismo su condición de cura propietario está documentada en AHASFVC, Parroquia de Naturales, Libro de Difuntos, 1734$1756, \mathrm{~s} /$ foliar.

89 AHASFVC, Libro de Oposiciones-Edictos y Autos- Inmunidades (1721-1780/1753/ 17221782), f.20v-22r. Buenos Aires, 25 de febrero de 1734.

90 «... en 28 de junio de 1781 toma colación y canónica institución del curato de Sn Roque de Naturales [...] Franco. Ant ${ }^{\circ}$ de Vera Muxica», en AHASFVC, Curato Naturales, Libro de Bautismos, Matrimonios 1761-1783, 166v.

Hispania Sacra, LXIII

128, julio-diciembre 2011, 433-467, ISSN: 0018-215-X 
nos. Asimismo las ausencias de estos párrocos por viajes o enfermedades o las vacantes generadas en caso de muerte, estuvo salvada por curas interinos o tenientes de cura como lo atestiguan las actas firmadas por Pedro del Monge, ${ }^{91}$ Vicente Troncosso, ${ }^{92}$ Francisco Javier Troncoso, ${ }^{93}$ Bartolomé Zubiría ${ }^{94}$ o Francisco Pantaleón Robledo, ${ }^{95}$ lo cual incidió también en la continuidad de los registros parroquiales. En este espacio abordaremos la información contenida en estos libros sólo para referir a su directa relación con en el aspecto configuracional del curato de naturales.

Una evidencia no puede dejar de resaltarse y es que correspondió a la gestión de Antonio de Oroño -1734-1762-96 el ordenamiento de los asientos de actas parroquiales de San Roque que hasta ese momento parece no haber tenido una rigurosa organización, ni la estrecha vigilancia que en este período ejerció la curia diocesana. Con la asunción de su ministerio, Oroño comenzó sus registros con notas de disposiciones y autos exponiendo como un gesto fundador de la institución lo que en verdad coincidía con su entrada inaugural al sistema beneficial. Así anotó: «Libro Primero de Bautismos y Olios que según el Conzilio Tridentino y dispossion de la Iglesia deben tener los curas, en el qual van tres traslados sacados, y autorizados en bastante forma». El primero de estos traslados era el título de cura proveído por el Gobernador, el segundo era la colación y canónica institución otorgada por el Provisor, vicario General y Gobernador Episcopal de la diócesis del Río de la Plata y el tercero un auto declaratorio que expresaba que a este cura pertenecía:

91 AHASFVC, Curato de Naturales, Libro de Bautismos 1733-1760, f.11. «A 18 del mes de Marso de 1735 años haciendo oficio de cura interinario (sic) el Mtro Dn Pedro del Monxe por estar yo enfermo se bautisaron y chrismaron con bautismo de adultos ...»

${ }^{92}$ A partir de 14 de junio de 1761 en AHASFVC, Curato Naturales, Libro de Difuntos, 1734-1756, s/foliar.

93 «Por el fallecimiento del Dor D. Pedro Joseph Crespo cura propietario de la parroq. del Sor San Roque el sor vic ${ }^{\circ}$ de esta ciud Dr D. Ant ${ }^{\circ}$ de Oroño hizo nombramiento de cura interino en mi el Dor D. Franco Xavier Troncoso el día quince de Junio de mil setecientos setenta y quatro...» en AHASFVC, Curato Naturales, Libro de Bautismos, Matrimonios 1761-1783, f.107v.

${ }_{94}$ Desde 8 de julio de 1774 al 28 de junio de 1781 cuando toma posesión Francisco Antonio de Vera Mugica AHASFVC, Curato Naturales, Libro de Bautismos, Matrimonios 1761-1783, f.108r y $166 \mathrm{v}$, respectivamente.

95 Firma como fraile predicador, teniente de cura de la parroquial de San Roque. Desde el 21 de julio de 1783 hasta 8 de noviembre de 1783 «por ausencia del propietario a la capital de Buenos Ayres» en AHASFVC, Curato Naturales, Libro de Bautismos, Matrimonios 1761-1783, f. 176 r.-f.179v.

96 AHASFVC, Iglesia Matriz, Libro Bautismos 1748-1760, f.143v-f.144 r.22 de septiembre de 1761.El 28 de enero de 1762 hizo oposición al curato de españoles de Santa Fe. Fue nominado en primer lugar y nombrado párroco de la Iglesia Matriz por el gobernador Pedro de Zevallos, el 6 de febrero recibió canónica institución por el Provisor y vicario general del obispado Joseph de Riglos y tomó posesión con el pbro. Manuel de Aguiar. 
«la feligresía de Yndios Naturales y demas mencionada de Negros, mulatos y mestizos a quien administrara los santos sacramentos y predicara el Sto Evangelio como tal su propio cura y estos le acudirán con los dros. y obvenciones que fueren costumbre y an acostumbrado llevar sus antecesores sin que ninguna persona se lo repugne ni ponga embarazo alguno pena de obediencia y de excomunion maior lata sententia una protrina canonica monicione in iure premisa ipso facto incurrenda». 97

La inserción de este auto está directamente vinculada a una contienda protagonizada por los dos párrocos de la ciudad. Cuando en 1734 se sustanció el pleito por la propiedad del curato de naturales, ${ }^{98}$ la superior justicia eclesiástica procuró restablecer su jurisdicción confirmando la canónica institución de su párroco y sentenciando al cura de españoles a respetarla bajo pena de excomunión mayor. El litigio había enfrentado a Joseph Martínez Monge, rector de la iglesia Matriz con Antonio Oroño quien denunció el avasallamiento cometido por el cura de españoles sobre los derechos exigidos a «su» feligresía.

La puja no presentaba una situación novedosa. Las contiendas suscitadas por el ejercicio de los respectivos ministerios parroquiales acusan escenarios propicios para esa conflictividad que atraviesan la larga existencia del curato de naturales.

Uno de ellos es el trazado por las prácticas devocionales en torno a las imágenes de culto, alojadas en esta iglesia, que convocaban a fieles que no estaban bajo las potestades jurisdiccionales del cura de naturales sino del cura de españoles. De allí el interés manifiesto por conservar su fábrica no fuera privativo de la feligresía asignada al curato de naturales.

Sabido es que ni indios, ni negros, ni mulatos podían acceder a la condición jurídica, ni gozar de la calidad de «vecinos», que eran quienes pedían socorro al Cabildo para sostener su edificio. ${ }^{99}$ El hecho de ser San Roque «abogado para los contagios y pestes», calamidades recurrentes que afectaban a la población en general, inspiraba expresiones devocionales que se plasmaban en la organización de rogativas, novenarios y procesiones que no se celebraban necesariamente en su iglesia. Las mismas implicaban sacar la imagen del santo de su templo, ponerla en circulación por las calles y, en ocasiones, depositarla por varios días en otras iglesias.

Este acto de ceder el ícono precursor de la parroquia no podía quedar librado a la voluntad del cura de naturales pues estaba indisolublemente unido a los derechos de altar y a las ofrendas piadosas y, por ello, correspondía gestionar

${ }^{97}$ AHASFVC, Curato de Naturales, Libro de Bautismos 1733-1760, f. 4v.

98 AHASFVC, Querellas, II, f.66-f.68. Buenos Aires, 19 de febrero, 1734-traslado a Santa Fe firmado 23 de febrero de 1734 .

99 AGSF, Actas de Cabildo, Tomo V, f.301v-f.303. Santa Fe, 2 de Septiembre de 1688; Tomo VII, f.32v -f 34.Santa Fe, 5 de Julio de 1710; Tomo X A, X f 186 a 187 v. Santa Fe, 19 de Diciembre de 1733. 
una autorización. Quien administraba esta licencia era el provisor y vicario general de la ciudad, cura de españoles, rector de la Iglesia Matriz. Estas circunstancias se constituyen como uno de los escenarios posibles donde el cura de españoles podía incurrir en injerencia jurisdiccional apropiándose de los derechos que correspondía al cura de naturales.

Del mismo modo, un escenario de probable conflictividad lo constituyó el auspiciado por la convergencia de las funciones anexas a cada curato y la ramificación de los vínculos conyugales que, cada vez más, fueron enlazando a hombres y mujeres procedentes de los diferentes grupos socioétnicos que la división parroquial pretendía anquilosar.

Las funciones de estos dos párrocos no diferían sustancialmente, ambos debían administrar sacramentos, predicar el Santo Evangelio a sus feligreses, quienes le debían acudir con los derechos y demás obvenciones, y asentar en los libros las actas de bautismo, matrimonio y defunción. Esta última, fue una tarea que, con motivo de la ajustada disquisición de los feligreses que suponía este criterio de división de las jurisdicciones parroquiales, demandó especial celo de parte de los curas.

Pese a que en su visita el obispo Joseph de Peralta de Barnuevo y Rocha anotó en el libro de bautismos de naturales que «lo halló mui conforme» y agradeció por ello al cura Oroño encargándole que prosiga de la misma suerte; 100 en el año 1756, el obispo Cayetano Marzellano y Agramont calificó negativamente su labor registral. Respecto de la formación de las partidas de casados y velados observó que no había cumplido con lo dispuesto por el Santo Concilio de Trento y encontró los registros «llenos de notorios substanciales defectos». ${ }^{101}$ Similar observación se notificó en el libro de bautismos en el cual Oroño había faltado a «la aplicación, cuidado y atención con que debía haber mirado siempre materia tan recomendada y delicada $\mathrm{p}^{\mathrm{r}}$ los insanables perjuicios qe puede acarrear falta tan considerable».102

Sin duda, la vigilancia de las autoridades episcopales fue perfeccionando el modo de confeccionar estos libros ya que, bajo apercibimiento de severas medidas, compelían al titular de la parroquia a que cumpliera exactamente con el ministerio de su cargo y arreglara las partidas tomadas. Para este propósito en varias oportunidades se libraron instrucciones con las fórmulas que establecían el orden de los datos que debía seguirse en los registros que de todos modos

100 AHASFVC, Parroquia de Naturales, Libro de Bautismos 1733-1760, f.16v. Santa Fe, 3 de febrero de 1742.

101 AHASFVC, Parroquia de Naturales, Libro de Difuntos, 1734-1756, s/foliar. Santa Fe, 17 de marzo de 1756. Visita Obpo. Cayetano Marzellano y Agramont.

102 AHASFVC, Parroquia de Naturales, Libro de Bautismos 1733-1760, f.45-46, Santa Fe, 17 de marzo 1756. 
siempre se practicaron en forma de breves relatos con los partícipes y condiciones del acto sacramental. Así la fórmula que transcribió el secretario de visita para realizar un acta de bautismo rezaba:

«En la ciud de Santa Fe de la Vera Cruz en la Iglesia de San Roque parroquia de Naturales en tal dia, mes y año yo el cura della bautisé, puse oleo y crisma, ô bautisó, puso oleo y crisma con mi licencia y asistencia el Rdo Pde Fray Fulano de tal orden ô el Dr ô Mrô Dn Fulano de tal, ô butisé ô bautisó sub conditione; ô puse ô puso olio y crisma (si esta bautisada en cassa la criatura por necesidad por persona conocida y de suficiencia) à fulano ô fulana de edad de tantos días meses ô años (y si fue bautisada en cassa se pone aquí a quien bautise, si se bautisso el propio) por necesidad o bautisó en cassa por necesidad el Rdo Pde Fray N ô el Dr ô Mrô Dn N, es hijo ô hija lexitimo ô lexitima de N y N Indios de tal parte, ô de fulano indio, negro, mulato o mestiso y de fulana india, negra, mulata o mestisa segun que fueren esclavo o esclavos de Dn $\mathrm{N}$ ô de $\mathrm{Da} \mathrm{N}$ ô de padres no conocidos, si no los tiene Fueron sus padrinos $\mathrm{N}$ y $\mathrm{N}$ explicando aquí los nombres y si no ay mas que padrino ô madrina, si fuere esclavo pondrá de quien y les explicara el parentesco, qe contrahen con el bautissado, y sus padres y lo relacionara assi en la partida. Y todo esto se ha de observar en todas las partidas». ${ }^{103}$

\section{Y la fórmula para el acta de matrimonio:}

«En la ciud de Sta Fe de la Vera Cruz en tantos de tal mes y tal año en la Ygla del Sor San Roque Parroquia de Naturales, yo el cura de ella cassé in facie ecclesie, velé, ô cassó con mi licencia in facie ecclesie, y beló el R. P, fr. fulano de tal, de tal orden, del Dor ô del Mtrô. Dn fulano. O cassó o veló, in facie ecclesie.

Si no es tiempo de velaciones, a fulano Indio, Negro, Mulato ô Mestizo, según que fuere, con fulana India, Negra, Mulata o Mestiza; y si alguno de los contrayentes fuere esclavo, o los dos, pondrá de quien; o si fuere o fueren libres, pondrán sus nombres y apellidos, expresando ser Libres o Mestizos. Y luego seguirá fueron testigos fulano y zutano, poniendo aquí los nombres y apellidos, y si son esclavos y de quien. Y luego cerrará la Partida diziendo doi fee, y abajo la autorización con su firma entera». ${ }^{104}$

En 1764 el obispo Manuel Antonio de la Torre para «evitar la introducion de nuevos abusos» y «corruptelas» también dejó instrucciones en su visita. La autoridad episcopal les exigió que lleven con mayor «puntualidad» el registro separado y detallado de bautismos, matrimonios y defunciones. ${ }^{105}$ En esta oportunidad el objetivo del requerimiento señalaba un conflicto puntual entre los párrocos santafesinos: «en atención a disputarse entre el presente cura y el

${ }^{103}$ AHASFVC, Parroquia de Naturales, Libro de Bautismos 1733-1760, f.45-46, Santa Fe, 17 de marzo 1756.

${ }^{104}$ AHASFVC, Parroquia de Naturales, Libro de Casados y Velados, 1752-1764, Santa Fe, f.22rf.23r.Santa Fe, 17 de marzo 1756.

105 AHASFVC, Parroquia de Naturales, Libro de Difuntos 1764-1787. Santa Fe, 26 de octubre de 1764.

Hispania Sacra, LXIII

128, julio-diciembre 2011, 433-467, ISSN: 0018-215-X 
cura de españoles sobre la pertenencia de entierros». ${ }^{106}$ Sucedía que al casarse los «españoles» o «españolas» con feligreses o feligresas de San Roque sobrevenían algunas perturbaciones entre los ministros a la hora de hacer efectivos los derechos de sepultura y que intentaban evitarse de parte de la autoridad episcopal.

Los mestizos en sus diversas denominaciones - pardo, moreno, mulato o mestizo- preocuparon en primer lugar, por su presencia numérica. ${ }^{107} \mathrm{La}$ complejidad del entramado social y la aparición de contradicciones y las fallas del edificio pigmentocrático, ${ }^{108}$ tal como había sido concebido en la Península y practicado en América, exacerbaron las inquietudes. Esto no significa que se haya logrado controlar completamente el «manejo social de lo étnico», ${ }^{109}$ pero la existencia y dinámica de parroquias diferenciadas se representó a los grupos dominantes como la panacea.

Así, se estableció, con un claro criterio patriarcal, que cuando un español se casara con una feligresa de San Roque, la parroquialidad de esta última, quedaría fijada en la Iglesia Matriz, «la qual debe ser Matriculada, con toda su casa y Familia, la que en los honores debe seguir al Padre». ${ }^{110}$

En esta dirección, la razón patriarcal fijaba que si el padre estaba en vida al morir esposa e hijos, estos serían enterrados en la Iglesia Matriz y, por el contrario, si la muerte de estos últimos acontecía cuando el feligrés español era difunto, los feligreses revertían al curato de naturales. Por el contrario, si una española se casaba con un feligrés de San Roque correspondía al párroco de naturales matricular a toda la familia y administrarles sacramentos. En este caso,

106 AHASFVC, Iglesia Matriz, Libro de Bautismos 1764-1785. Santa Fe, 27 de octubre de 1764.

107 F. LANGUE, «Le passeur malgré lui. L'aristocracie mantuana comme médiateur culturel.(Venezuela, XVIII' siècle)», en L. BÉNAT-TACHOT y S. GRUZINSKI -directeurs-Passeurs culturels: mécanismes de métissage, París, 2001, p.74. B. LAVAllé Transgressions et stratégies du métissage en Amérique coloniale, Paris, 1999.

108 B. LaVAlLÉ (directeur) Transgressions et stratégies du métissage en Amérique coloniale, Centre de recherche sur 1'Amérique espagnole coloniale, Presses Sorbonne Nouvelle, Paris, 1999, Introduction, 7 .

109 En este sentido ver el análisis de Bernard Lavallé sobre la Pragmática de 23 de marzo de 1776 de Carlos III que se proponía «como arma capaz de luchar contra el serio peligro constituido por el casamiento de personas de estatuto y nivel social diferentes que ponía en riesgo el adecuado orden social» y dio respaldo jurídico a las familias para interponerse en los matrimonios de los hijos. La misma se hizo extensiva a los territorios americanos en un primer momento por Cédula del 7 de abril de 1778 «excluyendo a las uniones que sólo concernían a mulatos, negros, mestizos y miembros de otras razas mixtas similares», luego incorporándolos en 1803 pero siempre legitimado acendrados prejuicios con renovada normativa que muchos lograron transgredir. Cfr. B. LAVALLÉ «¿Estrategia o coartada? El mestizaje según los disensos de matrimonio en Quito (1778-1818)» en Transgressions et stratégies..., Ibidem, p.98, acerca del complejo manejo de la etnicidad, p. 113 y ss.

110 AHASFVC, Parroquia de Naturales, Libro de Difuntos 1764-1787. Santa Fe, 26 de octubre de 1764. 
solamente, la muerte del esposo habilitaba la restitución de la feligresa y sus hijos al curato de españoles. Igualmente, se decretó que si los hijos o hijas de estos matrimonios se casaren «se tendrá consideración de los Maridos hasta que los Naturales pasen de Pichuelos, porque entonces ya se tienen por Españoles». 111

Estas normas fijadas como instrucciones para el asiento de los actos sacramentales en los libros parroquiales constituían verdaderos mojones en el deslinde de las jurisdicciones entre ambos curatos. Sin embargo, su estricto cumplimiento exigiría a ambos párrocos un control muy aguzado, casi impracticable, tanto del ejercicio del ministerio de su par como de la vida cotidiana e íntima de los feligreses.

El mestizaje no necesariamente pasaba por el sacramento del matrimonio ya que tanto indios, como españoles, negros, mulatos, pardos o mestizos, solían convivir en situación de concubinato. Pero además, algunos transgrediendo las condiciones previstas para un favorable informe de libertad y soltura, obtenían licencias de matrimonios que solapaban la mezcla. De hecho, en el citado ordenamiento, el obispo prevenía al cura de naturales que habiendo españoles casados con naturales, que «no pasan de Pichuelas». suspenda en la exploración de estas situaciones porque a su juicio, este accionar, resultaba muy odioso y perturbaba la vida conyugal.

El obispo reivindicaba que este último precepto -la paz conyugal- prevaleciera a «las temporales utilidades de el Parocho». Estas disposiciones, de ser llevadas a la práctica, además de favorecer la movilidad socio étnica ascendente de las desposadas, hacía del cura de la Matriz el mayor beneficiario. ${ }^{112}$ La recomendada suspensión de la exploración de estas uniones matrimoniales, amén de que podrían resultar odiosas y perturbadoras para la vida de los cónyuges, resultaron serlo para el cura de naturales ya que representaba un obstáculo insalvable para recuperar feligresas que migraban de curato llevándose consigo la factibilidad de la retribución por servicios religiosos administrados a ellas y, eventualmente, a sus hijos.

111 Idem.

112 De acuerdo con las notas fijadas en los márgenes de las hojas de cada renglón de los registros parroquiales, los montos percibidos por entierros y sepulturas eran más abultados cuando correspondían al cura de españoles. El cura de naturales podía realizar entierros en cualquiera de las iglesias de la ciudad: en la Matriz, en la de los conventos de San Francisco, Santo de Domingo o La Merced, en la de los jesuitas o en su propia iglesia de San Roque. Podía hacerlo de limosna o percibiendo sumas que iban entre los 2 y 5 pesos y -muy excepcionalmente 14 pesos. Por su parte el cura de españoles cobraba entre 20 y 39 pesos y ofrecía un variado repertorio de oficios de sepultura -misa cantada, misa sin vigilia y sin diáconos, misa cantada con vigilia y diacono, de cuerpo presente- y un despliegue de vestimentas y ornamentos adecuados a cada ocasión cuyas descripciones contrastan con las correspondiente de los utilizados en los oficios del cura de naturales.

Hispania Sacra, LXIII

128, julio-diciembre 2011, 433-467, ISSN: 0018-215-X 
En última instancia, aún cuando los obispos insistieron en el reconocimiento y asignación de las feligresías, al no existir una delimitación territorial, imposibilitada además por el acentuado proceso de mestizaje, el resguardo de la jurisdicción parroquial dependía directamente del criterio y la habilidad del párroco.

Como ha señalado Poloni-Simard, eran variados los mecanismos y las situaciones de mestizaje en un espacio urbano. ${ }^{113}$ Los matrimonios también podían efectuarse en el sentido inverso de la movilidad socio étnica, ${ }^{114}$ como lo hicieron, entre otros, un pardo libre de Santa Fe de 25 años con una española natural de Santa Fe viuda de primeras nupcias, ${ }^{115}$ un indio natural del Tucumán de 25 años con una española natural de Santa Fe viuda de primeras nupcias ${ }^{116}$ o un mestizo natural de Córdoba de 30 años con española natural de Santa Fe.117

Por último, aunque no en último lugar, la institucionalización del curato de naturales en las primeras décadas del siglo XVIII no fenecía en su talante configuracional por la particular gravitación que tuvo el proceso de creación de nuevos curatos rurales en la diócesis del Río de la Plata. Este proceso acompasó la primera gestión borbónica de los militares-gobernadores introduciendo transformaciones que como las señaladas por Tarragó, habían formalizado en la dinámica política de este territorio. ${ }^{118}$

A partir de 1730 las parroquias de españoles y de naturales de Santa Fe vieron desmembrarse de sus jurisdicciones las feligresías que se asignaron a los curatos del Pago de los Arroyos (1730), del Pago de la otra banda del río Paraná (1730) y del Pago de Coronda (1749). Contrariamente, el permanente ingreso a la ciudad de esclavos y de indios «rescatados» o «cautivos» de las campañas contra «los infieles», sobre cuya dimensión aún no ha podido expedirse la historiografía santafesina, ensancharon el sector afromestizo -mulatos, pardos- de la población que el párroco de naturales debía acoger como potenciales feligreses.

113 J. POLONI-SIMARD «Figures et configurations, formes et conformations du métissage: testaments indiens de Huamanga au XVIIe siècle», en L. BÉNAT-TACHOT y S. GRUZINSKI Ibidem.

114 Aunque en esta investigación no se completado la contabilización de los registros de la parroquia de naturales, sí hay evidencias de estas uniones en las informaciones suministradas al juez eclesiástico a quien concernía librar las licencias de matrimonio. La tarea que se impone a futuro es localizar las actas matrimoniales vinculadas a estas licencias y estimar si estas uniones son o no indicativas de gran importancia.

115 AHASFVC, Libro de información matrimonial, VII, 1756-1761. 15 de septiembre de 1757.

116 AHASFVC, Libro de información matrimonial VIII, 1762-1764.18 de agosto de 1762.

117 AHASFVC, Libro de información matrimonial VIII, 1762-1764. 2 de mayo de 1764.

118 G. TARRAGó, «Espacio, recursos y territorio: la Gobernación del Río de la Plata durante el reinado de Felipe V», en Actas de las III Jornadas de Historia de las Monarquías Ibéricas. Las Indias Occidentales: procesos de integración territorial (siglos XVI-XIX), El Colegio de México/Red Columnaria, México, 2009. 
Los libros de bautismo revelan la impronta de la cantidad de indios, en particular de niños y mujeres, que por «rescate» entraban con destino de servicio personal a las casas de los vecinos santafesinos. Aunque algunos registros declararon abiertamente esta condición, tal como la de «Xaviera india de 9 a 10 años traída del cautiverio de los infieles», 119 en otros aparece más solapada como ejemplo, los casos de una «india nación abipona convertida a ntra Santa Fe siendo adulta» 120 o el de «Lorenza de nación mocobí de un año no figuran padres». 121

Las historias que trasuntan estas actas parroquiales, los pleitos y los informes de libertad y soltura, sustanciados por los jueces eclesiásticos de Santa Fe, no solamente sugieren la relevancia del estudio de este curato para el estudio de las tendencias demográficas de un sector prácticamente no indagado, ${ }^{122}$ ofrecen también una excelente base documental para el conocimiento de otros aspectos de la vida de quienes, registrados como feligreses del curato de naturales procurándoles una calificación socioétnica, asoman involucrados en múltiples situaciones sociales, inmersos en diversos campos relacionales -económico, socio-cultural, doméstico, público- que invitan a ser explorados.

\section{UN FINAL INESPERADO}

Como se refirió en las primeras líneas, el curato de naturales santafesino se extinguió en 1787. En esa fecha, y hasta el último día de vigencia en los registros de los libros de la parroquia de San Roque, se especificó la condición socioétnica de sus feligreses. Al contrario de lo sucedido con el curato de naturales de la ciudad de Corrientes, ${ }^{123}$ su desaparición se resolvió con la unión de los dos curatos y la vigencia de los dos beneficios eclesiásticos anejos a sus párrocos; los motivos habrá que plantearlos como objeto de una investigación futura. El obispo Lué y Riega informó en su paso por Santa Fe: «Se visitó la unica Ygla. Parroquial de esta Ciudad, a la que está unida la de $\mathrm{S}^{\mathrm{n}}$. Roque antes

119 AASFVC, Libro de Bautismos Curato de Naturales, 1733-1760, f.14.

${ }^{120}$ Ibidem, f. 12.

${ }^{121}$ Ibidem, f. 13v.

122 En particular los esclavos como ha sostenido María del Rosario Baravalle. M. del R. BARAVALLE «Introducción a un tema sin historia. Negros esclavos en Santa Fe, siglo XVII» Claroscuro 1 (2001) 157-177; «Los esclavos y la esclavitud» en D. BARRIERA (coord.) Nueva historia de Santa Fe, Tomo III, Economía y sociedad (Siglos XVI a XVIII), Rosario, 2006.

${ }^{123}$ Aunque no menos conflictiva, la supresión del curato de naturales de Corrientes se resolvió nombrando a su párroco como sacristán mayor de la iglesia matriz. Al respecto E. MAEDER, Ibidem, nota $110,177$.

Hispania Sacra, LXIII

128, julio-diciembre 2011, 433-467, ISSN: 0018-215-X 
Parroquia de Naturales» y que servían el « $\mathrm{D}^{\text {or }}$. $\mathrm{D}^{\mathrm{n}}$. Fran ${ }^{\text {co }}$ de Vera y Muxica -Cura y Vicario y $\mathrm{D}^{\text {or. }} \mathrm{D}^{\mathrm{n}}$. Antonio Guzmán- Cura Rector». ${ }^{124}$

Su abolición, precipitada a dos años de la gestión del párroco Francisco Antonio de Vera Mujica, suscitó disconformidad entre los vecinos generando una animosidad contra el cura que sobrevivió hasta principios del siglo XIX. Las desavenencias reaparecieron en 1808 en ocasión de solicitarse la renovación de los dos beneficios parroquiales. En el cabildo santafesino se denunció que la representación hecha en 1786 por Francisco Antonio Quintana, como síndico procurador sustituto, pidiendo la fusión de los dos curatos, no debía tenerse en cuenta por «haberse verificado aprovechando una corta ausencia del titular, J. Crespo, y ser debido a la influencia que ejerce sobre él el Dr. Vera, a quien sirve de letrado». ${ }^{125}$ La sospecha se cernía contra quien había sido el último párroco de naturales porque, antes que deberse a la mengua de su feligresía, la fusión de curatos habría obedecido a sus pretensiones de acceder al curato rectoral. No hay dudas de que el altercado implica desovillar otra madeja de temas, de los cuales no se ocupa este artículo, pero el mismo debería ser considerado al tiempo de explicar las posibles razones de la desaparición del curato de naturales cuando aún pervivían idénticos conceptos para calificar aquellos habitantes de la ciudad que conformaron su feligresía y que fundamentaron su existencia.

\section{PALABRAS Finales}

Esta aproximación al conocimiento de las configuraciones eclesiales en territorio santafesino a través del estudio de las jurisdicciones parroquiales ha procurado exponer el proceso de institucionalización de un tipo particular de ellas -el curato de naturales- y una faceta de la vida urbana escasamente visibilizada en la historiografía regional: aquella en la que participan clérigos y feligreses.

Un inicio impreciso y unas actividades, documentalmente intermitentes, imprimen un carácter esquivo al estudio de la parroquia de naturales de San Roque durante el siglo XVII. Hacia el siglo XVIII, con la estabilización de las condiciones de sucesión de sus párrocos enmarcándose en los lineamientos jurídicos de la colación y canónica institución, este espacio llegó a representar una plaza importante para los clérigos y, en especial, una sólida plataforma para aquellos que hacían su ingreso al sistema beneficial.

${ }^{124}$ Cuaderno de la Santa y Pastoral Visita del obispo Benito Lué y Riega (1803-1805), copia facsimilar E. Stoffel, Santa Fe, 1992. Agradezco a María Elena Barral haberme facilitado este documento.

${ }^{125}$ AGSF, Actas de Cabildo, Tomo XVII B, f. 393-f. 398. Santa Fe, 8 de Agosto de 1808. 
Su afianzamiento no sólo dependió de estas condiciones de acceso y sucesión de sus titulares, sino también de la importancia conferida al perfil administrativo de la tarea de los párrocos y a su implicancia en la configuración jurisdiccional. La vigilancia de las autoridades episcopales en el ordenamiento de los asientos, su constante reglamentación y la continuidad en los registros que consiguieron las sucesivas gestiones parroquiales contribuyeron a la institucionalidad del curato de naturales y al deslinde de las jurisdicciones respecto del curato de españoles.

De todos modos, esto no garantizó una sosegada convivencia entre los párrocos de ambos curatos. La confrontación de intereses por las apetencias de rentas eclesiásticas y el creciente mestizaje continuaron sumando dificultades al tiempo de señalar los límites precisos del ejercicio curatal. Por estas razones los resultados de la indagación acerca del funcionamiento de la parroquia de naturales contribuye al discernimiento de la diversidad de las instituciones eclesiales, al tiempo que descubre aquella capa más oculta de la población urbana que constituyó su heterogénea feligresía de indios, negros, mulatos, pardos y mestizos y que borroneó los contornos del concepto de naturaleza.

Si el análisis de pleitos en la justicia eclesiástica y decretos diocesanos ha permitido detectar la conflictividad y litigiosidad en el interior del ámbito parroquial urbano, el registro del paso de estas personas por la parroquia de naturales constituye un observatorio de las concepciones socioétnicas en ese momento vigentes y las acciones encaminadas a la integración diferenciada y desigual de las castas en la comunidad local. De acuerdo con la lógica de Antiguo Régimen, la pertenencia a la parroquia de naturales constituyó un signo en la construcción de identidades desiguales. Estos feligreses, si bien se denominaron «naturales» por la naturalización que implicaba el nacimiento en la fe cristiana, no alcanzaron el estatuto de vecindad.

Indios y negros habían arribado a la ciudad en circunstancias -cautiverio, compra, traslado- que denotan las condiciones de dominación bajo las cuales habitaron la traza urbana. Fijar su parroquialidad implicó la intervención de sus amos y señores en cuyas casas urbanas cohabitaron y desde donde derivaron otras relaciones que incrementaron el número de mulatos, pardos y mestizos. Juntos en la casa, separados en la parroquia.

¿De qué modo intervinieron los señores en la fijación de la parroquialidad? ¿Siempre consintieron el adoctrinamiento de sus dependientes? ¿Qué nuevos vínculos inauguraba la identidad de feligreses de estos dependientes con sus señores y con otros miembros de la comunidad? ¿Cuántos feligreses congregaba la Parroquia de naturales?

Este artículo, obviamente, ni agota los interrogantes, ni puede ofrecer respuestas para los que abre tras un primer examen del problema. Para despejar es- 
tas cuestiones será fundamental, entre otras operaciones, profundizar el análisis cruzado de las declaraciones pertinentes a los requisitos para concretar el matrimonio que registraron los jueces eclesiásticos con las informaciones contenidas en los libros parroquiales. Hasta aquí, sólo queda expuesta documentadamente la complejidad de las dinámicas relacionales mestizas en este espacio.

El conocimiento de la configuración y funcionamiento del curato de naturales de Santa Fe es, sin duda, un laboratorio privilegiado para el estudio de esta dimensión del pasado colonial. 